\title{
Contribution of brain pericytes in blood- brain barrier formation and maintenance: a transcriptomic study of cocultured human endothelial cells derived from hematopoietic stem cells
}

Marjolein Heymans ${ }^{1}$, Ricardo Figueiredo ${ }^{2,3}$, Lucie Dehouck' ${ }^{1}$ David Francisco ${ }^{4}$, Yasuteru Sano ${ }^{5}$, Fumitaka Shimizu ${ }^{5}$, Takashi Kanda ${ }^{5}$, Rémy Bruggmann ${ }^{4}$, Britta Engelhardt ${ }^{6}$, Peter Winter ${ }^{2}$, Fabien Gosselet ${ }^{1}$ and Maxime Culot $^{1 *}$ (D)

\begin{abstract}
Formation, maintenance, and repair of the blood-brain barrier (BBB) are critical for central nervous system homeostasis. The interaction of endothelial cells (ECs) with brain pericytes is known to induce BBB characteristics in brain ECs during embryogenesis and can be used to differentiate human ECs from stem cell source in in vitro BBB models. However, the molecular events involved in BBB maturation are not fully understood. To this end, human ECs derived from hematopoietic stem cells were cultivated with either primary bovine or cell line-derived human brain pericytes to induce BBB formation. Subsequently, the transcriptomic profiles of solocultured vs. cocultured ECs were analysed over time by Massive Analysis of cDNA Ends (MACE) technology. This RNA sequencing method is a 3'-end targeted, tag-based, reduced representation transcriptome profiling technique, that can reliably quantify all polyadenylated transcripts including those with low expression. By analysing the generated transcriptomic profiles, we can explore the molecular processes responsible for the functional changes observed in ECs in coculture with brain pericytes (e.g. barrier tightening, changes in the expression of transporters and receptors). Our results identified several upand downregulated genes and signaling pathways that provide a valuable data source to further delineate complex molecular processes that are involved in BBB formation and BBB maintenance. In addition, this data provides a source to identify novel targets for central nervous system drug delivery strategies.
\end{abstract}

Keywords: Blood-brain barrier, ${ }_{1}$, Transcriptome 2 , BBB formation ${ }_{3}$, In vitro ${ }_{4}$, Central nervous system ${ }_{5}$, Brain endothelial cells ${ }_{6}$, Human hematopoietic stem cells $s_{7}$, Brain pericytes 8

*Correspondence: maxime.culot@univ-artois.fr

1 Laboratoire de la Barrière Hémato-Encéphalique (LBHE), Univ. Artois, UR 2465, 62300 Lens, France

Full list of author information is available at the end of the article

\section{Background}

Brain capillary endothelial cells (ECs) display unique characteristics when compared to ECs from peripheral vasculature, e.g. tight junctions, low pinocytic activity, expression of metabolic enzymes, transporters, receptors and efflux pumps [24]. These characteristics are known to be the blood-brain barrier (BBB) phenotype which constitute the $\mathrm{BBB}[2,11]$. The $\mathrm{BBB}$ is the interface between

c) The Author(s) 2020. This article is licensed under a Creative Commons Attribution 4.0 International License, which permits use, sharing, adaptation, distribution and reproduction in any medium or format, as long as you give appropriate credit to the original author(s) and the source, provide a link to the Creative Commons licence, and indicate if changes were made. The images or other third party material in this article are included in the article's Creative Commons licence, unless indicated otherwise in a credit line to the material. If material is not included in the article's Creative Commons licence and your intended use is not permitted by statutory regulation or exceeds the permitted use, you will need to obtain permission directly from the copyright holder. To view a copy of this licence, visit http://creativeco mmons.org/licenses/by/4.0/. The Creative Commons Public Domain Dedication waiver (http://creativecommons.org/publicdomain/ zero/1.0/) applies to the data made available in this article, unless otherwise stated in a credit line to the data. 
the systemic circulation and the central nervous system and is essential to maintain brain homeostasis, thereby restricting the entry of many pathogens, toxins and compounds into the brain [1]. Several of these brain capillary EC characteristics mentioned above are demonstrated not to be intrinsic to brain ECs, however, they result from the regulation of cellular and non-cellular factors produced by different cell types of the neurovascular unit (NVU), e.g. astrocytes, pericytes, neurons, neuroglia and peripheral immune cells $[9,11,30]$. The specific crosstalk between brain ECs and brain pericytes is known to induce BBB characteristics (e.g. expression and functionality of tight junction proteins, decreasing leukocyte adhesion molecule expression, decreasing transcytosis and induction of the basement membrane) in ECs during embryogenesis in vivo $[11,30]$. Pericytes are a type of vascular cells embedded in the basement membrane, thereby they wrap the cerebral capillary walls, with a pericyte coverage being the highest in neural tissue [30]. The latter implicates the importance of pericytes for BBB functioning, which is as well indicated by studies that relate pericytes to barrier function and regulation of inflammatory responses $[9,22]$. The pericyte-brain EC interaction is also used to differentiate ECs from stem cell source to human brain-like ECs which are used in in vitro BBB models $[7,21,23,36]$. These in vitro models should display barrier tightening, i.e. induced by coculture, in order to be of use for pharmaceutical screening. However, the underlying molecular events involved in development, maturation and maintenance of BBB features, are not fully understood and difficult to study in vivo, especially in humans. In particular, the BBB regulation related to the communication between pericytes and brain ECs remains largely unknown $[5,15,22]$.

In the present study, we make use of a human in vitro BBB model developed by Cecchelli et al. [7] consisting in ECs derived from hematopoietic stem cells which are cocultivated with brain pericytes. After 5 days of coculture with brain pericytes, the ECs were shown to display features of the BBB which were absent when the cells were cultivated alone: the co-cultivated ECs display a continuous expression of ZO-1, occludin, JAM-A, claudin-1 and claudin-5 at cell-cell contacts resulting in a lower permeability to non-permeant marker than when the cells were solocultivated. These cocultivated ECs also express several transporters typically observed in brain endothelium in vivo (e.g. $A B C B 1$ and $A B C G 2)$ [7].

To study the molecular processes responsible for the observed changes in ECs (i.e. barrier tightening, changes in the expression of transporters and receptors) in coculture with brain pericytes of ECs derived from hematopoietic stem cells cultivated with brain pericytes from either primary bovine or cell line human origin in a Transwell system using the Massive Analysis of cDNA Ends (MACE) technology. This RNA sequencing method is a $3^{\prime}$-end targeted, tag-based, reduced representation transcriptome profiling technique, that can reliably quantify all polyadenylated transcripts including those with low expression. By analysing the generated transcriptomic profiles, we can explore the molecular processes responsible for the functional changes observed in ECs in coculture with brain pericytes.

To specifically focus on the pericyte-EC interaction, we decomposed the model in either solo- or cocultured ECs. Human ECs were cultivated (in a non-contact setup) with either human pericytes (CHP) or with bovine brain pericytes $(\mathrm{CBP})$. In both coculture conditions, the ECs display BBB characteristics like restrictive tight junctions, low paracellular permeability to integrity markers and functional expression of polarized uptake and efflux transporters [7]. We subsequently compared the transcriptomic profile of cocultured ECs to the transcriptomic profile of solocultured ECs to delineate the transcriptional changes occurring in the ECs during barrier establishment. Besides the transcriptomic data, $\mathrm{BBB}$ functions were assessed by drug accumulation and permeability studies to preliminary validate the physiological relevance of the used in vitro model.

Transcriptomic profiling was done using high-throughput mRNA sequencing in combination with the digital gene expression profiling technique of GenXPro (Frankfurt am Main, Germany), the MACE technology. MACE performs gene expression profiling by sequencing part of the $3^{\prime}$-end of mRNA transcripts. Since each sequenced read represents one single mRNA molecule, the MACE technique can accurately quantify polyadenylated transcripts using a considerably lower sequencing depth than that of standard RNA-sequencing protocols, for which the number of fragments per transcript depends on the length of the transcript.

Our results provide a transcriptomic landscape of human brain-like ECs in solo- or coculture with brain pericytes that was used to identify interesting gene profiles over time, soloculture enriched transcripts, coculture enriched transcripts, etc., which might prove to be valuable in the further delineation of complex molecular processes involved in BBB formation and regulation. The transcriptomic profile could also be used as a source for novel targets for central nervous system drug delivery strategies.

\section{Materials and methods Compounds}

The compounds lucifer yellow ( $\mathrm{LY} ; \mathrm{Mw}=457.25 \mathrm{~g} \mathrm{~mol}^{-1}$ ), rhodamine 123 (R123; $\mathrm{Mw}=380.82 \mathrm{~g} \mathrm{~mol}^{-1}$ ) and elacridar $\left(\mathrm{GF} ; \mathrm{Mw}=563.65 \mathrm{~g} \mathrm{~mol}^{-1}\right)$ and other materials 
like bovine serum albumin and dimethyl sulfoxide, were purchased from Sigma-Aldrich (St. Quentin Fallavier, France).

All powdered compounds were dissolved in dimethyl sulfoxide or Krebs-Ringer HEPES (RH) buffer $(\mathrm{NaCl}$ $150 \mathrm{mM}, \mathrm{KCl} 5.2 \mathrm{mM}, \mathrm{CaCl}_{2} 2.2 \mathrm{mM}, \mathrm{MgCl}_{2} 0.2 \mathrm{mM}$, $\mathrm{NaHCO}_{3} 6 \mathrm{mM}$, glucose $2.8 \mathrm{mM}$, HEPES $5 \mathrm{mM}$, sterile water for injection $-\mathrm{pH}: 7,4)$. The source and origin of all other materials used in this study are detailed throughout the methodology.

\section{Cell culture}

\section{Soloculture of hematopoietic stem cell-derived endothelial} cells

The human in vitro BBB model used in this study was modified from the coculture model of Cecchelli et al. [7]. In brief, hematopoietic stem cell-derived ECs were isolated according to the method described in Cecchelli et al. [7]. Vials of frozen ECs $\left(1 \times 10^{6}\right.$ cells $)$ were rapidly thawed and seeded in gelatin-coated (type A from porcine skin) (Sigma-Aldrich) 100-mm Petri dishes (Costar, Corning Incorporated, NY, USA) containing complete medium for ECs i.e. endothelial cell medium (Sigma-Aldrich), supplemented with 5\% fetal calf serum (Integro), $1 \%$ endothelial cell growth supplement (SigmaAldrich) and 0.5\% gentamicin (Biochrom AG, Berlin, Germany). Two days after defrosting, around $5.0 \times 10^{6}$ cells were present and ECs were trypsinized with trypsin/ ethylenediaminetetraacetic acid $(0.05 \% / 0.02 \%$ in phosphate buffered saline-calcium and magnesium free (Biochrom AG) and seeded on a semi-permeable Transwell insert $(0.4 \mathrm{~mm}, 12$-well system, Costar, Corning Incorporated) coated with Matrigel (growth factor reduced BD Matrigel Matrix, BD Biosciences), at a concentration of $16.0 \times 10^{4}$ cells $/ \mathrm{mL}$. Cells were cultivated at $37{ }^{\circ} \mathrm{C}$ in a humified atmosphere at $5 \% \mathrm{CO}_{2} / 95 \%$ air for a total of 7 days and medium was changed every 2 days. All sera were heat-inactivated before use.

\section{Coculture of stem cell-derived ECs with brain pericytes}

Primary bovine brain pericytes were isolated from the brain of freshly killed cows obtained from the slaughterhouse of Douai, France according to the method described by Vandenhaute et al. [36]. Vials of frozen primary bovine brain pericytes (passage $\leq 3 ; 1.0 \times 10^{6}$ cells) were rapidly thawed and seeded in gelatin-coated 100$\mathrm{mm}$ Petri dishes containing complete medium for bovine pericytes (Dulbecco's modified eagle's medium (Gibco, Thermo Fisher Scientific, Villebon-sur-Yvette, France) supplemented with $20 \%$ fetal calf serum, $1 \%$ L-glutamine (Merck Chemicals, Darmstadt, Germany) and 0.5\% gentamicin). After 2 days, bovine pericytes were trypsinized and seeded, at a concentration of $1.3 \times 104 \mathrm{cells} / \mathrm{cm}^{2}$ on the bottom of gelatin-coated 12-well plates (Costar, Corning Incorporated).

The cell line of Human brain pericytes (hBPCT cell line) was provided by Yamaguchi University, Japan and derived from primary brain pericytes of a patient that died from a heart attack isolated and immortalized with retroviral vectors harboring a SV40 large T antigen gene according to the method described by Shimizu et al. [32]. Vials of frozen human brain pericyte between passage 15 and $25\left(1.0 \times 10^{6}\right.$ cells $)$ were rapidly thawed and seeded onto rat tail collagen (type I)-coated (BD Biosciences) 100-mm Petri dishes containing complete medium for human pericytes (Dulbecco's modified eagle's medium supplemented with $10 \%$ fetal calf serum, $1 \% \mathrm{~L}$-glutamine and $1 \%$ penicillin-streptomycin (Sigma-Aldrich)). The rat tail collagen was prepared as described by Dehouck et al. [12]. After 2 days, human pericytes were trypsinized and seeded, at a concentration of $1.3 \times 10^{4}$ cells $/ \mathrm{cm}^{2}$ on the bottom of rat tail collagen type I-coated 12-well plates.

Bovine and human brain pericytes were thawed 2 days before starting the coculture with ECs. Both cocultures were initiated by inserting the Transwell membranes with attached ECs into the pericyte-containing 12-well plates and by changing medium to endothelial cell medium, resulting in a non-contact BBB in vitro model, as no physical interaction exist between the two cell types. Experiments were initiated at different time points (i.e. 0, 24, 48 and $96 \mathrm{~h}$ ) starting from t0, as the moment of coculture initiation. Cocultures were cultivated at $37{ }^{\circ} \mathrm{C}$ in a humified atmosphere and $5 \% \mathrm{CO}_{2}$. All sera were heat-inactivated before use.

\section{Drug accumulation and permeability studies Permeability experiments}

At the different time points after putting ECs in coculture (i.e. 0, 24, 48, 72, 96 and $120 \mathrm{~h}$ ), permeability experiments were performed to assess the EC monolayer tightness according to the method described in Vandenhaute et al. [36]. In brief, permeability was assessed by calculating the permeability coefficient of a fluorescent integrity marker (i.e. LY). To initiate experiments, Transwell inserts containing confluent monolayers of ECs, were loaded with $0.5 \mathrm{~mL}$ donor solution (i.e. $\mathrm{LY}(50 \mathrm{mM})$ in $\mathrm{RH}$ buffer) and were subsequently placed in a new 12-well plate filled with preheated $\mathrm{RH}$ buffer $(1.5 \mathrm{~mL})$. Cells were subsequently incubated $\left(37{ }^{\circ} \mathrm{C}, 5 \% \mathrm{CO}_{2}\right)$ for exactly $60 \mathrm{~min}$ after which aliquots were taken from the initial donor solution $(\mathrm{C} 0)$ and from the donor and receiver solutions at the end of the experiment (De) and (Re). The fluorescence intensity, hence, concentration of LY, was determined by using a fluorescence multiwell plate reader (Synergy H1 multiplate reader, BioTek Instruments SAS, 
Colmar, France), using a LY filter pair of $\operatorname{Ex}(\lambda)$ 432; Em ( $\lambda$ ) $538 \mathrm{~nm}$. Experiments were done in triplicate (i.e. 3 inserts), hence a total of 3 inserts with (i.e. filter + cells) and 3 inserts without (i.e. only filter) cells were assessed per condition. Simultaneously, blank wells were prepared using the same solution to assess background values for subtraction from the measured values.

The permeability coefficient $\left(\mathrm{Pe}\right.$, in $\mathrm{cm} \mathrm{min}^{-1}$ ) and clearance were calculated according to the clearance principle described by Siflinger-Birnboim et al. [33]. The clearance principle was used to obtain a concentrationindependent transport parameter.

The cleared volume $(\mathrm{CL}$, in $\mathrm{mL}$ ) was calculated by dividing the diffused amount of compound in the receiver compartment (Ar) with the concentration of compound in the donor compartment (Cd) (Eq. 1).

$$
\text { Clearance }(C L, \text { in } \mathrm{mL})=A_{r} / C_{d}
$$

The average cumulative CL was subsequently plotted over time and the slope was estimated by linear regression analysis. This resulted in the permeability-surface area product (PS, in $\mathrm{mL} \mathrm{min}^{-1}$ ). To make a correction for permeability across cell-free inserts, the PS products was calculated for both cell-free inserts (i.e. PSf, filter) and inserts with cells (Eq. 2).

$$
P S_{t}=P S_{f}+P S_{e}
$$

The true or absolute Pe was then computed out of PSf and PSt (Eq. 3), normalized by the surface $\left(\mathrm{S}\right.$, in $\left.\mathrm{cm}^{2}\right)$ (Eq. 4) $[7,16,36]$.

$$
\begin{aligned}
& P S e^{-1}=P S t^{-1}-P S f^{-1} \\
& P e\left(\text { in } \mathrm{cm} \mathrm{min}^{-1}\right)=\frac{P S e}{S}
\end{aligned}
$$

The mass balance or recovery (in \%) was determined to avoid deviating results due to a possible loss of the tracer by e.g. adsorption to plastics and non-specific binding to cells. The recovery was calculated by dividing the amount of recovered compound at the end of the experiment by the initial amount of tracer at $\mathrm{t} 0$. For Pe determination, a threshold recovery range was adopted between 80 and $120 \%$.

\section{Rhodamine accumulation studies}

Drug accumulation assays were performed to evaluate functional activity of P-gp in ECs. The solo- and cocultured ECs were incubated for $2 \mathrm{~h}$ with R123 (5 mM) in $\mathrm{RH}$ buffer (supplemented with $0.1 \%$ bovine serum albu$\mathrm{min})$ with or without GF $(0.5 \mathrm{mM})$. After incubation, ECs were washed 3 times with ice-cold RH buffer and were subsequently lysed with lysis buffer $(10 \times$ RIPA lysis buffer, Millipore Merck, Darmstadt, Germany). Fluorescence detection was performed with the fluorescence multiwell plate reader, using an R123 filter pair of $\operatorname{Ex}(\lambda)$ 501; $\mathrm{Em}(\lambda) 538 \mathrm{~nm}$. Experiments were done at $37^{\circ} \mathrm{C}$ in a humified atmosphere at $5 \% \mathrm{CO}_{2}$.

\section{Statistical analysis}

All results were expressed as means with standard deviation from three or more independent experiments. Statistical significance was assessed by the unpaired Student's t-tests with two-tailed distribution, assuming equal standard deviation, or otherwise specified. A $\mathrm{p}$-value $<0.05$ was considered as significant (" $\mathrm{p}<0.05$; *** $<<0.005, * \%$, $<0.001)$. All statistical analyses were performed using GraphPad Prism 7 for Mac OS X (GraphPad Software, San Diego, California, USA).

\section{RNA sequencing: Massive Analysis of CDNA Ends (MACE) technology Total RNA isolation}

RNA isolation was performed at GenXPro GmbH. Cell lysates were stored in liquid nitrogen before RNA isolation. Isolation of total RNA from ECs was performed using the ZR-Duet DNA/RNA MiniPrep Plus kit (Zymo Research, Irvine, CA, USA) according to manufacturer's instructions. RNA samples were digested using DNase I and RNA integrity was accessed using automated capillary electrophoresis (RNA pico sensitivity assay, LabChip GX II Touch HT, Perkin Elmer, Villebon-sur-Yvette, France).

\section{Generation of MACE libraries and RNA sequencing}

We performed genome-wide gene expression profiling of solo- and cocultured ECs at $0,24,48$ and $96 \mathrm{~h}$ after putting ECs in coculture (3 biological replicates each consisting of 3 technical replicates) using the MACE method to identify differentially expressed genes upon pericyte introduction. The biological replicates were defined as coming from different vials of frozen ECs. These replicates originate from the cord blood of 1 or 2 donors. For each biological replicate, we subsequently pooled 3 inserts (i.e. technical replicates). Hence, a total of 9 replicates was used.

Preparation of a next-generation sequencing library and subsequent RNA sequencing was performed at GenXPro GmbH. A number of 27 MACE libraries was constructed using the MACE-Seq kit v2.0 (GenXPro $\mathrm{GmbH}$ ) according to the supplier's protocol. MACEsequencing is a $3^{\prime}$-end targeted, tag-based, reduced representation transcriptome profiling technique that can reliably quantify all polyadenylated transcripts. 
In general, the procedure follows a modified protocol described in Nold-Petry et al. [29]. In brief, samples with 100 ng of DNase-treated RNA were used for library preparation. Synthesis of cDNA was performed by reverse transcription using oligo $(\mathrm{dT})$ primers following fragmentation of cDNA to an average size of $200 \mathrm{bp}$ using sonification (Bioruptor, Diagenode, Seraing, Belgium). DNA was quantified using a Qubit HS dsDNA assay (Thermo Fisher Scientific). cDNA fragments were ligated to DNA adapters containing TrueQuant unique molecular identifiers included in the kit. Library amplification was done using polymerase chain reaction, purified by solid phase reversible immobilization beads (Agencourt AMPure XP, Beckman Coulter, Brea, CA, USA) and subsequent sequencing was performed using a NextSeq platform (Illumina Inc., San Diego, CA, USA).

\section{Bioinformatic analysis of MACE data}

A total of approximately 391 million MACE reads was obtained across all libraries (Additional file 1). Polymerase chain reaction-duplicates were identified using the TrueQuant technology and subsequently removed from raw data. All remaining reads were further poly (A)-trimmed and low-quality reads were removed, after which clean reads were aligned to the human reference genome $^{1}$ using the bowtie 2 mapping tool. The latter resulted in a gene dataset with a total of 25,684 different genes. The gene count data was normalized to account for differences in library size and RNA composition bias by calculating the median of gene expression ratios using DESeq $2 \mathrm{R} /$ Bioconductor package [27]. This resulted in a p-value and $\log 2$-fold change $(\log 2 \mathrm{FC})$ for every gene for 2 conditions. False discovery rate was estimated to account for multiple testing. During bioinformatic analysis, differentially expressed transcripts were identified using a combination of thresholds for $\mathrm{p}$-value $<0.05$ and $|\log 2 \mathrm{FC}|>1$, as performed by Munji et al. [28]. During experimental design, these thresholds were considered to be correct to analyse even the most subtle changes in gene expression during the time course of the experiment, due to the characteristics of the experimental setup, biological questions and analysis. Additionally, the accurate quantification of mRNA transcripts using MACE sequencing allowed identification of differentially expressed genes using the combination of $\mathrm{p}$-value and $\log 2 \mathrm{FC}$.

Differentially expressed genes were further categorized in solo- and coculture enriched genes. The ratio between the normalized expression of a specific gene in solocultured ECs and the normalized expression of the same

${ }^{1}$ hg38, http://genome.ucsc.edu/cgi-bin/hgTables. gene in cocultured ECs resulted in soloculture enriched genes if the ratio exceeded 2, or otherwise specified. The ratio between the normalized expression of a specific gene in cocultured ECs and the normalized expression of the same gene in solocultured ECs resulted in cocultured enriched genes if the ratio exceeded 2. To obtain enriched genes, some thresholds were made to ensure to have taken into account only valuable genes (i.e. raw data count of the enriched condition $>20$, exclusion of pseudogenes and non-coding genes).

Genes were further assigned to biological pathways to analyse signaling and metabolic pathways by using the Gene Ontology (GO) enrichment tool (GenXPro $\mathrm{GmbH}$ ), the Ingenuity Pathway Analysis and the KOBAS web server. These functional enrichment tools were used to evaluate the functional properties of gene sets, thereby resulting in over- or underrepresented GO terms for a set of genes that were up- or downregulated in our comparisons. The used software consists of databases that classifies genes according to their roles in the cell, allowing to identify 'pericyte or coculture enriched' signaling pathways [18]. Statistical analysis of the GO enrichment analysis consisted of the Fisher's exact test among transcripts that were differentially expressed at a p-value $<0.05$.

\section{Availability of data}

The generated transcriptomic data for this study, including both the raw data and the counts matrix, has been deposited in the Gene Expression Omnibus (GEO) database with the ascension ID of GSE144474. The data will also be made available at the BBBHub (http://bbbhu b.unibe.ch) upon launch.

\section{Results}

Influence of brain pericytes on functional barrier properties: Barrier tightness and efflux transporter functionality

The effect of brain pericytes on the barrier tightness and efflux transporter functionality in ECs was assessed by permeability studies to determine the tightness of the endothelial monolayer and by drug accumulation studies to assess functionality of ATP-binding cassette $(\mathrm{ABC})$ efflux transporters e.g. P-glycoprotein (P-gp/ABCB1/ MDR1) and breast cancer resistance protein (BCRP/ ABCG2).

The ECs monolayer's tightness was investigated by studying the $\mathrm{Pe}$ of the commonly used hydrophilic integrity marker, LY, across the endothelial cell monolayer. Both pericyte co-cultures (i.e. CBP and CHP) significantly decreased the permeability to LY over time (Fig. 1). The Pe to LY for solocultured ECs remained higher and relatively stable throughout the whole-time range, with an average over time of $1.36 \pm 0.27 \times 10^{-3}$ 


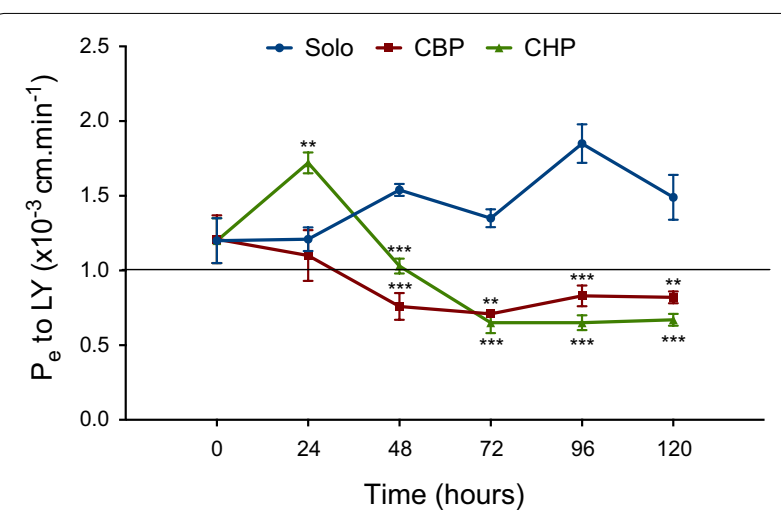

Fig. 1 Endothelial permeability coefficient $\left(P_{e}\right)$ to $L Y(50 \mathrm{mM})$ over time of the endothelial cell monolayer in soloculture (solo, blue), in coculture with bovine pericytes (CBP, red) and in coculture with human pericytes (CHP, green). Data is shown as a mean $(\mathrm{N}=3) \pm$ standard deviation, statistics were done by a two-tailed unpaired t-test and a significantly different $P_{e}$ to $L Y$ in CBP or CHP compared to soloculture is indicated by ${ }^{*} p<0.05,{ }^{* *} p<0.005$, and ${ }^{* * *} \mathrm{p}<0.001$

$\mathrm{cm} \cdot \mathrm{min}^{-1}$. The Pe to LY for the CBP and CHP decreased, when compared with the Pe of the solocultured ECs, and this by $37 \%(\mathrm{CBP})$ and $14 \%(\mathrm{CHP})$ after $48 \mathrm{~h}$, by $31 \%$ (CBP) and $46 \%$ (CHP) after $96 \mathrm{~h}$ and by $32 \%(\mathrm{CBP})$ and $45 \%$ (CHP) after $120 \mathrm{~h}$. The Pe to LY is $1.10 \pm 0.17 \times 10^{-3} \mathrm{~cm} \mathrm{~min}^{-1}$ and $1.72 \pm 0.07 \times 10^{-3}$ $\mathrm{cm} \mathrm{min}{ }^{-1}$ after $24 \mathrm{~h}$ and $0.82 \pm 0.04 \times 10^{-3} \mathrm{~cm} \mathrm{~min}^{-1}$ and $0.67 \pm 0.04 \times 10^{-3} \mathrm{~cm} \mathrm{m^{-1 }}$ after $120 \mathrm{~h}$ for the
CBP and CHP respectively. These results demonstrate a common reduction of endothelial permeability over time for ECs cocultured with brain pericytes, which confirms the involvement of brain pericytes in regulating and/or inducing important BBB features. The latter has been shown by several other studies $[8,10,11,22]$.

The functionality of the P-gp and BCRP efflux pumps was evaluated by a drug accumulation assay with P-gP and BCRP substrate R123. Cells were incubated with R123 in presence and absence of a P-gp and BCRP inhibitor, GF. Our results evidence the presence of functional efflux pumps in both solo- and cocultured ECs as demonstrated by an increased intracellular accumulation of R123 in presence of inhibitor (i.e. $43 \%$ and $42 \%$ for the CBP and CHP, respectively), compared to the baseline condition (i.e. depicting R123 accumulation in absence of GF) (Fig. 2a). Although not significantly different from the cocultured ECs, the difference between the intracellular accumulation of R123 in absence and in presence of inhibitor seems to be somewhat higher in the solocultured ECs. This is also reflected by the transcriptomic data (Fig. 2b) that shows an overall downregulation of P-GP and a decreasing expression of BCRP over time in cocultured ECs compared to solocultured ECs. Several studies show a pericyte-enhanced P-gp function or a higher P-GP expression in rodent brain vasculature compared to peripheral vasculature $[10,11,15]$. The latter is not reflected by our data.
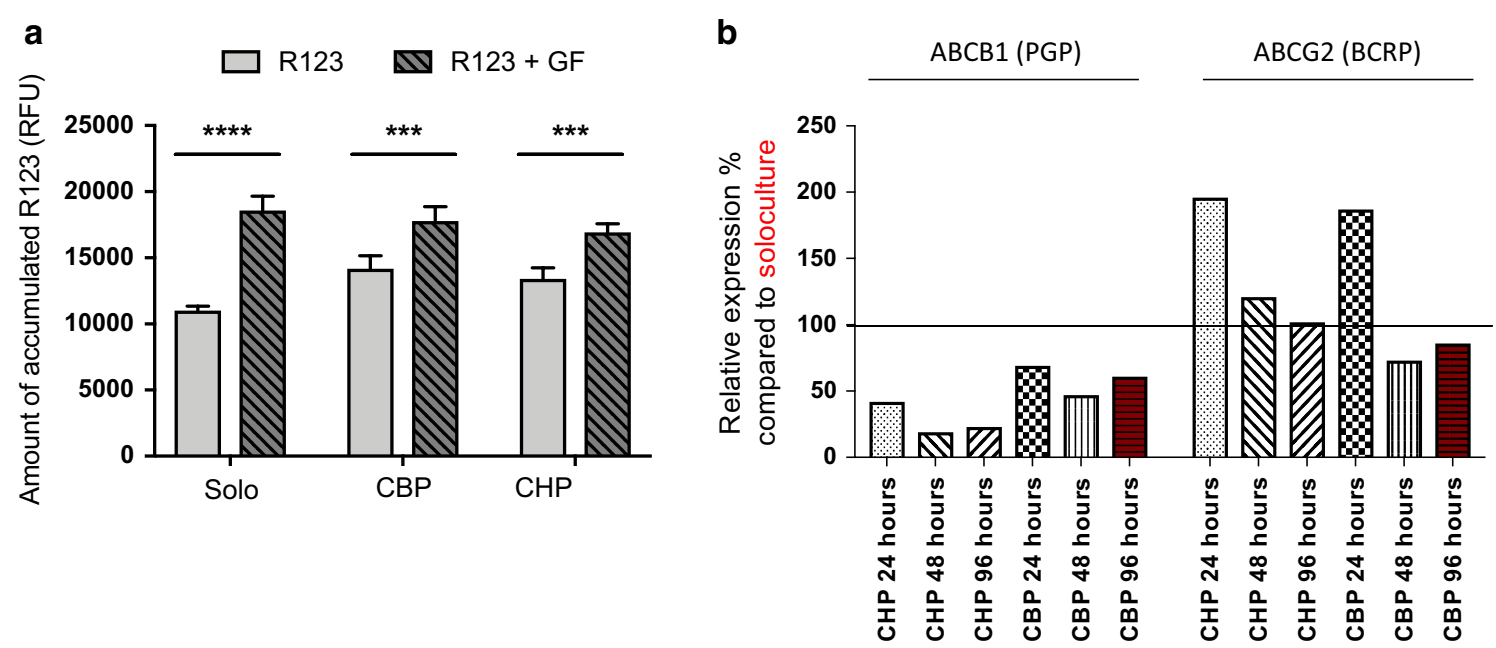

Fig. 2 a Efflux pump activity measured by the intracellular accumulation of rhodamine 123 (R123) in absence (red) or presence (green, lines) of the inhibitor, elacridar (GF) in solocultured endothelial cells (Solo), or in cocultured endothelial cells with bovine pericytes (CBP) and cocultured endothelial cells with human pericytes (CHP). Data is shown as the mean amount intracellular accumulated R123 with standard deviation (in $\mathrm{RFU})(\mathrm{N}=3)$. $\mathbf{b}$ Expression profile of ABC efflux transporters P-gp and BCRP in endothelial cells cocultured with human pericytes $(\mathrm{CHP}$, green) or bovine pericytes (CBP, red). Expression is depicted as relative expression (in \%) compared to the expression in solocultured endothelial cells at the corresponding time points 
Table 1 Summary of different clusters of gene responses

\begin{tabular}{|c|c|c|c|c|c|c|c|}
\hline & $\begin{array}{l}\text { Differentially } \\
\text { expressed } \\
\%\end{array}$ & $\begin{array}{l}\text { Down- } \\
\text { regulated } \\
\text { (p-value }<\end{array}$ & $\begin{array}{l}\text { Up-regulated } \\
|\log 2 \mathrm{FC}| \mid>1)\end{array}$ & Total regulated & $\begin{array}{l}\text { Down- } \\
\text { regulated } \\
\text { (p-value < }\end{array}$ & $\begin{array}{l}\text { Up-regulated } \\
|\log 2 F C|>2)\end{array}$ & Total regulated \\
\hline \multicolumn{8}{|c|}{ CBP vs. Solo (h) } \\
\hline 24 & 5.8 & 207 & 114 & $321(1.2 \%)$ & 49 & 26 & $75(0.3 \%)$ \\
\hline 48 & 14.6 & 302 & 343 & 645 (2.5\%) & 70 & 109 & 179 (0.7\%) \\
\hline 96 & 15.1 & 513 & 253 & 766 (3.0\%) & 148 & 72 & $210(0.8 \%)$ \\
\hline \multicolumn{8}{|c|}{ CHP vs. SOLO (h) } \\
\hline 24 & 20.4 & 414 & 534 & 948 (3.7\%) & 41 & 199 & 240 (0.9\%) \\
\hline 48 & 16.1 & 297 & 561 & 858 (3.3\%) & 54 & 188 & 242 (0.9\%) \\
\hline 96 & 18.7 & 644 & 591 & $1235(4.8 \%)$ & 114 & 260 & $374(1.5 \%)$ \\
\hline
\end{tabular}

The percentage of differentially expressed transcripts $(p<0.05)$ is shown in the second column for every condition and is depicted as a percentage of the total number (i.e. 25684 ) of mapped genes. Column 3 and 4 show differentially expressed transcripts in cocultured vs. solocultured endothelial cells characterized by a $\mid$ og $2 \mathrm{FC} \mid>1$. Column 6 and 7 depict differentially expressed transcripts characterized by a $|\log 2 \mathrm{FC}|>2$

Influence of brain pericytes on the transcriptomic profile of brain-like endothelial cells

To identify the influence of brain pericytes on the transcriptomic expression profile of ECs, we utilized the MACE RNA sequencing technique. Therefore, we compared the gene expression of solocultured ECs to the gene expression of cocultured ECs.

\section{Influence of pericytes on the global gene expression profile of brain-like endothelial cells}

The MACE gene expression profiling of ECs in soloculture or in coculture with brain pericytes identified several clusters of gene responses: (i) up- or downregulated genes in cocultured ECs compared to solocultured ECs; (ii) up- or downregulated genes in ECs in the CBP compared to solocultured ECs; (iii) up- or downregulated genes in ECs in the CHP compared to solocultured ECs; and (iv) up- or downregulated genes at specific time points in cocultured ECs compared to solocultured ECs (Table 1).

Figure 3a shows the number of differentially expressed genes $(|\log 2 \mathrm{FC}|>1)$ for the comparison between cocultured ECs and solocultured ECs over time. This graph indicates an increase in differentially expressed genes over time for both cocultures, as well as it shows a higher number of differentially expressed genes in ECs from $\mathrm{CHP}$ compared with CBP. Figure $3 \mathrm{~b}$ shows the number of differentially expressed genes $(|\log 2 \mathrm{FC}|>2)$ for the comparison between cocultured ECs and solocultured ECs over time. This graph shows (i) a higher number of differentially expressed genes in the comparison of soloculture vs. CHP, compared to the comparison of soloculture vs. CBP; (ii) an increased amount of differentially expressed genes over time for both the comparison of soloculture vs. coculture in general; and (iii) a clearly higher number of upregulated differentially expressed genes compared to downregulated differentially expressed genes for the comparison soloculture vs. CHP, which is not reflected in the comparison soloculture vs. CBP.

These results suggest that coculturing with human pericytes affects the gene expression profile more rapidly and slightly more than coculturing with bovine pericytes. However, the influence of pericytes is minor in both cases, as no more than $5 \%$ of the total number of genes is altered significantly upon coculturing. However, numerous genes are significantly affected ( $\mathrm{p}$-value $<0.05$ and $|\log 2 \mathrm{FC}|>1)$ or $|\log 2 \mathrm{FC}|>2)$, but the change in expression levels is small, indicating a low responsiveness towards factors originating from pericytes.

\section{Enriched gene expression}

Differentially expressed genes were categorized in soloculture enriched and coculture enriched genes. Genes were identified as soloculture enriched when expressed at high levels in soloculture conditions and poorly or not expressed in coculture conditions. The opposite was true for coculture enriched genes. Our results indicate an increased number of soloculture enriched genes over time (ratio $\geq 3$ ) (Fig. 4a), as well as an increased number of coculture enriched genes over time (ratio $\geq 3$ ) (Fig. 4b) (i.e. for both the CHP and the CBP). Interestingly, the identified number of soloculture enriched genes in the comparison with the CHP shows to be threefold higher than for any other comparison.

A list of the ten of most enriched soloculture and coculture genes, for every comparison at each time point, was generated (Tables 2,3). Within this list, genes that were identified to be enriched in both comparisons (i.e. soloculture vs. CHP and soloculture vs. CBP) are depicted in bold. These top regulated genes (Tables 2, 3) are partially validated by Ingenuity Pathway Analysis as several of the coculture enriched genes are found back in the list of top 

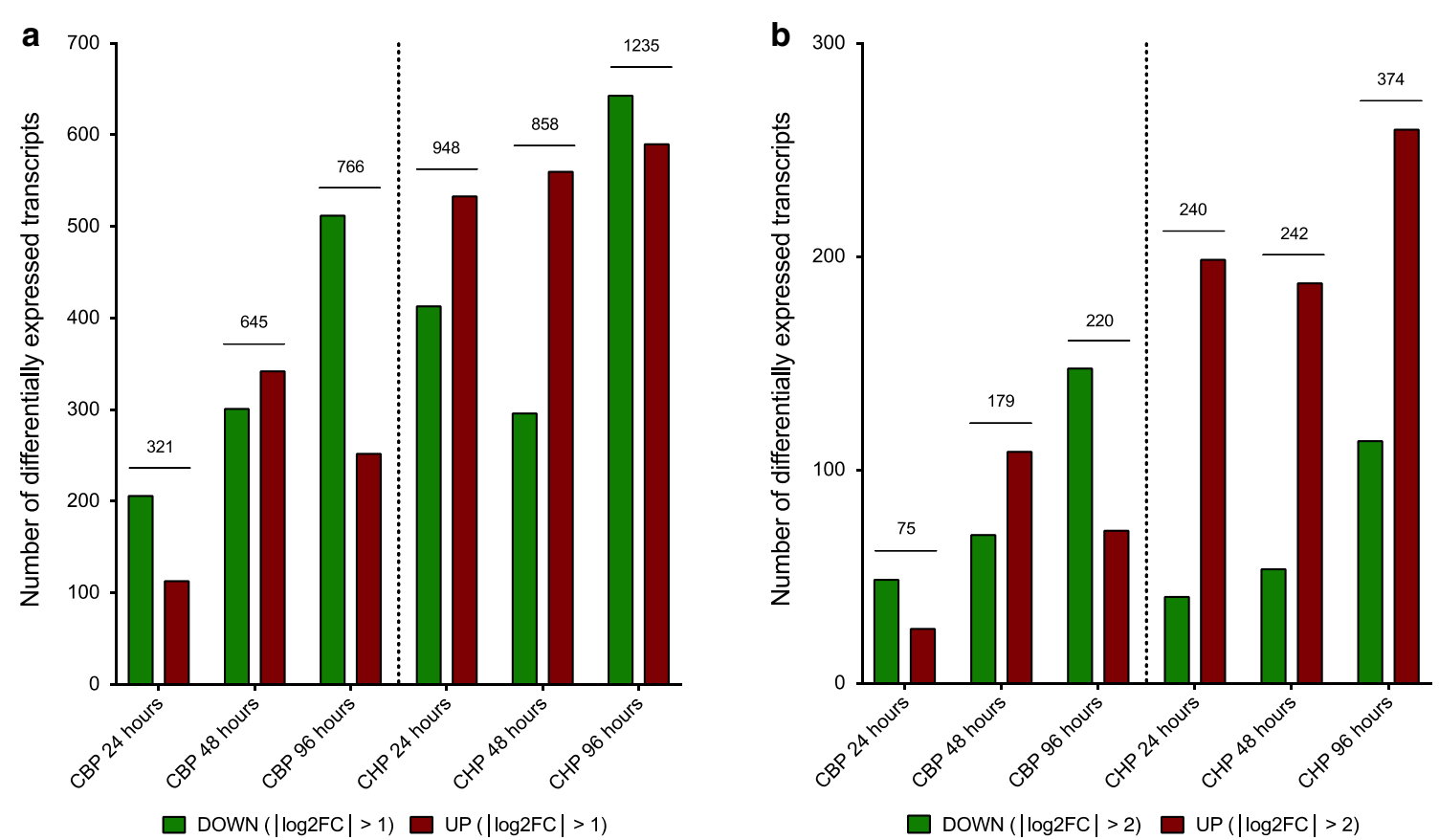

Fig. 3 Number of differentially expressed transcripts for the cocultured vs. solocultured endothelial cells at different time points i.e. 24, 48 and $96 \mathrm{~h}$. Coculture conditions were depicted as CBP for coculture with bovine pericytes and CHP for cocultures with human pericytes. Differentially expressed transcripts are characterized by $(\mathbf{a})$ a $|\log 2 \mathrm{FC}|>1$; and $\mathbf{b}$ a $|\log 2 \mathrm{FC}|>1$ and categorized in up- (green)- and down- (red) regulated transcripts in cocultured endothelial cells compared with their expression in solocultured endothelial cells. The total number of transcripts in line with these statistics are depicted on top of the bars
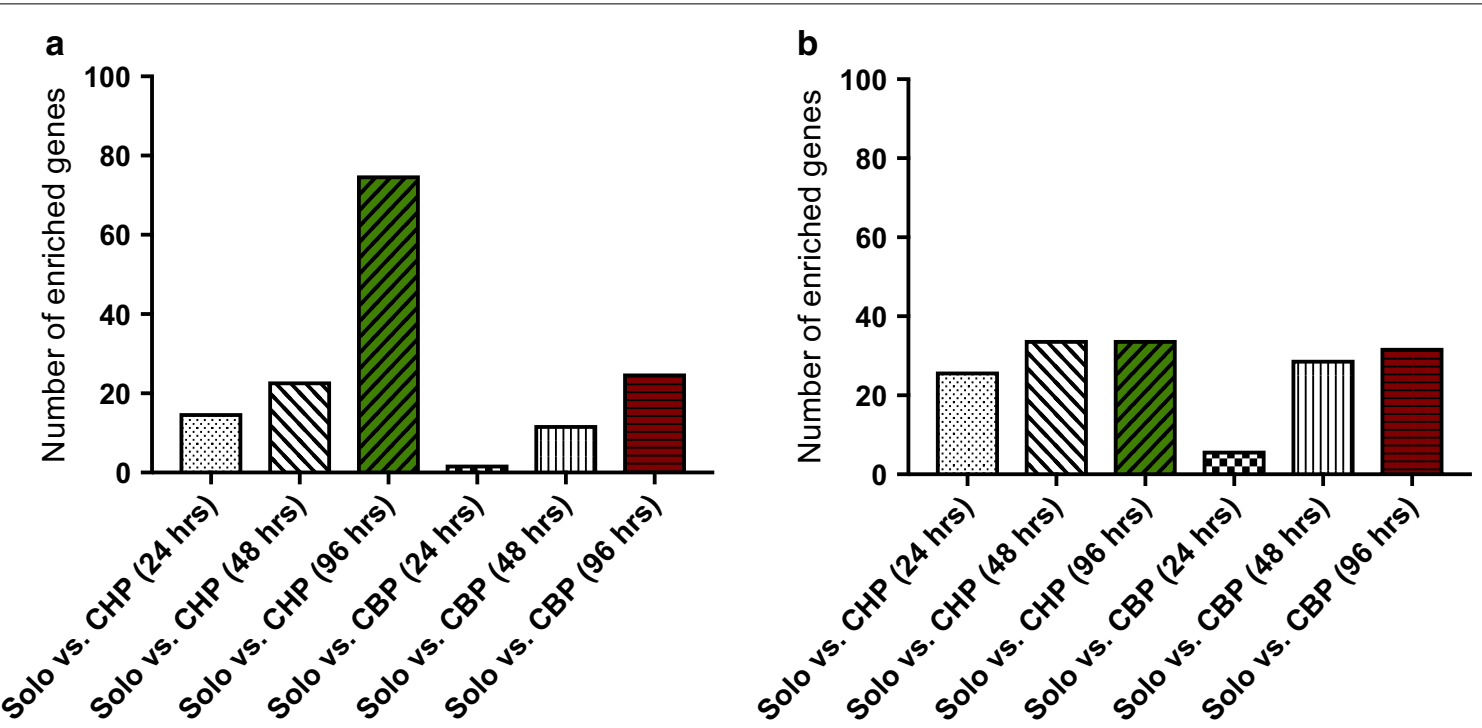

Fig. 4 a Number of soloculture enriched genes (ratio $\geq 3$ ) for solo- vs. coculture comparisons at different time points i.e. 24,48 and 96 h. b Number of coculture enriched genes (ratio $\geq 3$ ) for solo- vs. coculture comparisons. Coculture with bovine pericytes (CBP) depicted in red and coculture with human pericytes (CHP) depicted in green. The comparisons at $24 \mathrm{~h}$ were performed with a soloculture at $0 \mathrm{~h}$, as no analysis was performed for a soloculture at $24 \mathrm{~h}$ 
Table 2 Top 10 of the most enriched soloculture genes at 24 h (top), 48 h (middle) and 96 h (bottom) for (A) the comparison of soloculture (Solo) vs. coculture with human pericytes (CHP); and for (B) the comparison of soloculture vs. coculture with bovine pericytes (CBP)

\begin{tabular}{|c|c|c|c|c|}
\hline Gene & Gene description & $\begin{array}{c}\text { Ratio } \\
\text { Solo/CHP }\end{array}$ & p-value & $\log 2 \mathrm{FC}$ \\
\hline ID2 & $\begin{array}{l}\text { inhibitor of DNA binding 2, dominant } \\
\text { negative helix-loop-helix protein }\end{array}$ & 7.2 & $7.26 \mathrm{E}-10$ & 2.8 \\
\hline ESM1 & endothelial cell-specific molecule 1 & 4.4 & $2.07 \mathrm{E}-19$ & 2.1 \\
\hline CCL2 & chemokine (C-C motif) ligand 2 & 4.1 & $2.68 \mathrm{E}-09$ & 2.0 \\
\hline HTR2B & $\begin{array}{l}\text { killer cell lectin-like receptor subfamily } \\
G, \text { member } 1\end{array}$ & 3.8 & $2.76 \mathrm{E}-08$ & 1.9 \\
\hline ANXA3 & annexin $A$ & 3.8 & $4.65 \mathrm{E}-07$ & 1.9 \\
\hline BMPER & BMP binding endothelial regulator & 3.7 & $7.95 \mathrm{E}-08$ & 1.9 \\
\hline BAMBI & $\begin{array}{l}\text { BMP and activin membrane-bound } \\
\text { inhibitor }\end{array}$ & 3.4 & $1.20 \mathrm{E}-06$ & 1.7 \\
\hline EGR1 & early growth response 1 & 3.3 & $4.26 \mathrm{E}-12$ & 1.7 \\
\hline IGFBP7 & $\begin{array}{l}\text { insulin-like growth factor binding protein } \\
7\end{array}$ & 3.1 & $2.32 \mathrm{E}-08$ & 1.6 \\
\hline CYR61 & cysteine-rich, angiogenic inducer, 61 & 3.1 & $4.68 \mathrm{E}-04$ & 1.6 \\
\hline CRHBP & $\begin{array}{l}\text { corticotropin releasing hormone binding } \\
\text { protein }\end{array}$ & 31.8 & $4.38 \mathrm{E}-16$ & 5.0 \\
\hline BMPER & $B M P$ binding endothelial regulator & 9.7 & $4.26 \mathrm{E}-16$ & 3.3 \\
\hline FABP4 & fatty acid binding protein 4 , adipocyte & 7.5 & $3.23 \mathrm{E}-25$ & 3.0 \\
\hline GJA4 & gap junction protein, alpha $4,37 \mathrm{kDa}$ & 7.2 & $7.67 \mathrm{E}-09$ & 2.9 \\
\hline CLEC3B & C-type lectin domain family 3 , member $B$ & 6.3 & $2.62 \mathrm{E}-23$ & 2.7 \\
\hline ID2 & $\begin{array}{l}\text { inhibitor of DNA binding 2, dominant } \\
\text { negative helix-loop-helix protein }\end{array}$ & 5.3 & $1.43 \mathrm{E}-08$ & 2.4 \\
\hline EPHX4 & epoxide hydrolase 4 & 5.2 & $4.37 \mathrm{E}-07$ & 2.4 \\
\hline ABCB1 & $\begin{array}{l}\text { ATP-binding cassette, sub-family } B \\
(M D R / T A P), \text { member } 1\end{array}$ & 5.2 & $5.38 \mathrm{E}-15$ & 2.4 \\
\hline GUCY1A3 & guanylate cyclase 1 , soluble, alpha 3 & 5.0 & $3.08 \mathrm{E}-09$ & 2.3 \\
\hline SESN3 & sestrin 3 & 4.3 & $5.69 \mathrm{E}-08$ & 2.1 \\
\hline BMPER & BMP binding endothelial regulator & 88.7 & $1.32 \mathrm{E}-28$ & 6.2 \\
\hline CRHBP & $\begin{array}{l}\text { corticotropin releasing hormone binding } \\
\text { protein }\end{array}$ & 24.3 & $1.48 \mathrm{E}-11$ & 4.4 \\
\hline EGR3 & early growth response 3 & 22.1 & $8.70 \mathrm{E}-21$ & 3.7 \\
\hline FABP4 & fatty acid binding protein 4 , adipocyte & 18.8 & $2.81 \mathrm{E}-33$ & 3.2 \\
\hline ACP5 & acid phosphatase 5 , tartrate resistant & 10.8 & $3.77 \mathrm{E}-14$ & 2.7 \\
\hline GJA5 & gap junction protein, alpha $5,40 \mathrm{kDa}$ & 10.6 & $2.74 \mathrm{E}-15$ & 2.6 \\
\hline NR4A1 & $\begin{array}{l}\text { nuclear receptor subfamily } 4 \text {, group } A \text {, } \\
\text { member } 1\end{array}$ & 9.2 & $1.55 \mathrm{E}-08$ & 2.6 \\
\hline ID2 & $\begin{array}{l}\text { inhibitor of DNA binding 2, dominant } \\
\text { negative helix-loop-helix protein }\end{array}$ & 8.9 & $2.00 \mathrm{E}-13$ & 2.6 \\
\hline EPHB1 & EPH receptor $B 1$ & 8.2 & $1.67 \mathrm{E}-08$ & 2.6 \\
\hline GJA4 & gap junction protein, alpha $4,37 \mathrm{kDa}$ & 8.0 & $2.63 \mathrm{E}-11$ & 2.6 \\
\hline
\end{tabular}

regulated genes from the Ingenuity Pathway Analysis (data not shown).

As overlapping genes between the two cocultures can be a first type of validation, a full comparison of overlapping genes in both comparisons was made. For this, we assessed the number of overlapping enriched genes in both comparisons (i.e. solo- vs. CHP and solo- vs. CBP). We only included those enriched genes that were characterized by a ratio $\geq 2$ (Table 4 and 5 ). This assessment indicated that both soloculture and coculture overlapping enriched genes increase in number over time.

\section{Gene expression profile of specific genes}

We also assessed the gene expression profile over time for some specific gene groups related to the BBB i.e. vascular permeability genes, junction associated genes, tight junction and tight junction associated genes, ABC transporter genes and endothelial marker genes (Fig. 5), as 
Table 2 (continued)

\begin{tabular}{|c|c|c|c|c|}
\hline Gene & Gene description & $\begin{array}{c}\text { Ratio } \\
\text { Solo/CBP }\end{array}$ & p-value & $\log 2 \mathrm{FC}$ \\
\hline DUSP8 & dual specificity phosphatase 8 & 5.3 & $1.91 \mathrm{E}-08$ & 2.4 \\
\hline CREB5 & $\begin{array}{l}\text { cAMP responsive element binding protein } \\
5\end{array}$ & 3.3 & 4.49E-08 & 1.7 \\
\hline MIF & $\begin{array}{l}\text { macrophage migration inhibitory factor } \\
\text { (glycosylation-inhibiting factor) }\end{array}$ & 2.6 & 0.16 & 1.4 \\
\hline EGR1 & early growth response 1 & 2.4 & $2.37 \mathrm{E}-06$ & 1.3 \\
\hline IL4I1 & interleukin 4 induced 1 & 2.4 & $1.04 \mathrm{E}-08$ & 1.1 \\
\hline IL32 & interleukin 32 & 2.2 & $7.54 \mathrm{E}-08$ & 1.1 \\
\hline RELB & $\begin{array}{l}\text { v-rel avian reticuloendotheliosis viral } \\
\text { oncogene homolog } B\end{array}$ & 2.2 & $1.70 \mathrm{E}-03$ & 1.1 \\
\hline TGFB2 & transforming growth factor, beta 2 & 2.1 & $2.63 \mathrm{E}-05$ & 1.1 \\
\hline ARL4C & ADP-ribosylation factor-like $4 C$ & 2.1 & $1.39 \mathrm{E}-04$ & 1.0 \\
\hline VCAM1 & vascular cell adhesion molecule 1 & 2.1 & $1.11 \mathrm{E}-04$ & 1.0 \\
\hline CYP1A1 & $\begin{array}{l}\text { cytochrome P450, family 1, subfamily } A \text {, } \\
\text { polypeptide } 1\end{array}$ & 34.6 & $4.00 \mathrm{E}-13$ & 5.1 \\
\hline CRHBP & $\begin{array}{l}\text { corticotropin releasing hormone binding } \\
\text { protein }\end{array}$ & 8.8 & $5.42 \mathrm{E}-12$ & 3.1 \\
\hline BMPER & BMP binding endothelial regulator & 8.3 & $2.18 \mathrm{E}-15$ & 3.1 \\
\hline HTR2B & $\begin{array}{l}\text { killer cell lectin-like receptor subfamily } \\
G, \text { member } 1\end{array}$ & 5.0 & $4.25 \mathrm{E}-10$ & 2.3 \\
\hline GUCY1A3 & guanylate cyclase 1, soluble, alpha 3 & 4.7 & 4.41E-09 & 2.2 \\
\hline GJA4 & gap junction protein, alpha $4,37 \mathrm{kDa}$ & 4.4 & $5.28 \mathrm{E}-06$ & 2.1 \\
\hline EPHX4 & epoxide hydrolase 4 & 4.1 & $2.76 \mathrm{E}-06$ & 2.0 \\
\hline FABP4 & fatty acid binding protein 4 , adipocyte & 3.9 & $9.46 \mathrm{E}-14$ & 2.0 \\
\hline SESN3 & sestrin 3 & 3.5 & $5.85 \mathrm{E}-07$ & 1.8 \\
\hline ID2 & $\begin{array}{l}\text { inhibitor of DNA binding 2, dominant } \\
\text { negative helix-loop-helix protein }\end{array}$ & 3.4 & $4.47 \mathrm{E}-06$ & 1.8 \\
\hline EGR3 & early growth response 3 & 72.9 & $1.46 \mathrm{E}-24$ & 6.5 \\
\hline CYP1A1 & $\begin{array}{l}\text { cytochrome P450, family 1, subfamily A, } \\
\text { polypeptide } 1\end{array}$ & 21.6 & $1.67 \mathrm{E}-22$ & 4.6 \\
\hline BMPER & BMP binding endothelial regulator & 13 & $1.11 \mathrm{E}-22$ & 4.5 \\
\hline FABP4 & fatty acid binding protein 4 , adipocyte & 8.9 & $1.78 \mathrm{E}-46$ & 4.2 \\
\hline NR4A1 & $\begin{array}{l}\text { nuclear receptor subfamily } 4 \text {, group } A \text {, } \\
\text { member } 1\end{array}$ & 6.5 & $1.58 \mathrm{E}-24$ & 3.4 \\
\hline GJA5 & gap junction protein, alpha $5,40 k D a$ & 6.2 & $5.02 \mathrm{E}-16$ & 3.4 \\
\hline GJA4 & gap junction protein, alpha 4, 37kDa & 6.1 & $9.15 \mathrm{E}-16$ & 3.2 \\
\hline CRHBP & $\begin{array}{l}\text { corticotropin releasing hormone binding } \\
\text { protein }\end{array}$ & 6.1 & $2.81 \mathrm{E}-12$ & 3.2 \\
\hline NOS1 & nitric oxide synthase 1 (neuronal) & 6.0 & 4.27E-09 & 3.0 \\
\hline ATP2A3 & ATPase, $\mathrm{Ca}++$ transporting, ubiquitous & 5.9 & $8.43 \mathrm{E}-10$ & 3.0 \\
\hline
\end{tabular}

Shading color highlights soloculture enriched genes that are identified to be in the top 10 of two (light grey) or all time points (dark grey)

well as the gene expression profile of solute carrier (SLC) transporter genes (Fig. 6). The latter shows a major clustering in the expression of these genes of both cocultures at $48 \mathrm{~h}$ and $96 \mathrm{~h}$ in one cluster and soloculture at 0,48 and $96 \mathrm{~h}$ together with both cocultures at $24 \mathrm{~h}$ in another cluster. Addition of pericytes is shown to lead to different responses for the different conditions (Figs. 5, 6). Most of these responses were already identified by other studies $[6,10,11]$.

Interestingly, among the gene expression profiles of known vascular permeability genes, the plasmalemma vesicle-associated protein (PLVAP) expression is highly increased at $24 \mathrm{~h}$ for both cocultures, however it decreases drastically from 24 to $96 \mathrm{~h}$. The expression of the intercellular adhesion molecule 1 (ICAM1) and angiopoietin 1 (ANGPT1) is decreased in both cocultures compared to the soloculture (Fig. 5). The expression profile of several junction associated genes is altered upon the presence of brain pericytes compared to its expression in ECs alone (Fig. 5). And the relative gene expression pattern of several tight junction and tight junction associated genes suggests that important tight junction 
Table 3 Top 10 of the most enriched coculture genes at $24 \mathrm{~h}$ (top), $48 \mathrm{~h}$ (middle) and $96 \mathrm{~h}$ (bottom) for (A) the comparison of soloculture (Solo) vs. coculture with human pericytes (CHP); and for (B) the comparison of soloculture vs. coculture with bovine pericytes (CBP)

\begin{tabular}{|c|c|c|c|c|}
\hline Gene & Gene description & $\begin{array}{c}\text { Ratio } \\
\text { CHP/Solo }\end{array}$ & p-value & $\log 2 \mathrm{FC}$ \\
\hline HIST1H4C & histone cluster $1, \mathrm{H} 4 \mathrm{c}$ & 43.5 & $7.45 \mathrm{E}-13$ & -5.4 \\
\hline EXOC3L2 & exocyst complex component 3-like 2 & 26.1 & $1.04 \mathrm{E}-24$ & -4.7 \\
\hline ACKR1 & $\begin{array}{l}\text { atypical chemokine receptor } 1 \text { (Duffy } \\
\text { blood group) }\end{array}$ & 17.1 & $6.82 \mathrm{E}-32$ & -4.1 \\
\hline INMT & indolethylamine $N$-methyltransferase & 11.1 & $1.63 \mathrm{E}-13$ & -3.5 \\
\hline $\mathrm{A} 2 \mathrm{M}$ & alpha-2-macroglobulin & 7.7 & $1.15 \mathrm{E}-16$ & -3.0 \\
\hline SIRPB2 & signal-regulatory protein beta 2 & 7.5 & $3.62 \mathrm{E}-09$ & -2.9 \\
\hline ZNF366 & zinc finger protein 366 & 5.9 & $1.29 \mathrm{E}-07$ & -2.6 \\
\hline CCL23 & chemokine (C-C motif) ligand 23 & 5.2 & $1.63 \mathrm{E}-11$ & -2.4 \\
\hline PRR11 & proline rich 11 & 5.0 & $1.06 \mathrm{E}-08$ & -2.3 \\
\hline MMP1 & $\begin{array}{l}\text { matrix metallopeptidase } 1 \text { (interstitial } \\
\text { collagenase) }\end{array}$ & 4.9 & $3.91 \mathrm{E}-20$ & -2.3 \\
\hline STC1 & stanniocalcin 1 & 57.9 & $1.37 \mathrm{E}-23$ & -5.6 \\
\hline HIST1H4C & histone cluster $1, \mathrm{H} 4 \mathrm{c}$ & 25.5 & $9.27 \mathrm{E}-11$ & -4.5 \\
\hline ACKR1 & $\begin{array}{l}\text { atypical chemokine receptor } 1 \text { (Duffy } \\
\text { blood group) }\end{array}$ & 21.0 & $6.67 \mathrm{E}-28$ & -4.4 \\
\hline NPR3 & natriuretic peptide receptor 3 & 12.7 & $3.70 \mathrm{E}-19$ & -3.7 \\
\hline INHBB & inhibin, beta $B$ & 9.9 & $1.24 \mathrm{E}-16$ & -3.3 \\
\hline SLC2A3 & $\begin{array}{l}\text { solute carrier family } 2 \text { (facilitated } \\
\text { glucose transporter), member } 3\end{array}$ & 7.5 & $5.95 \mathrm{E}-25$ & -2.9 \\
\hline EXOC3L2 & exocyst complex component 3-like 2 & 7.0 & $4.31 \mathrm{E}-13$ & -2.8 \\
\hline SOCS3 & suppressor of cytokine signaling 3 & 6.9 & $8.95 \mathrm{E}-46$ & -2.8 \\
\hline CADM3 & cell adhesion molecule 3 & 5.8 & $1.10 \mathrm{E}-11$ & -2.5 \\
\hline ODF3B & outer dense fiber of sperm tails $3 B$ & 5.6 & $2.60 \mathrm{E}-14$ & -2.5 \\
\hline HISTAH4C & histone cluster $1, \mathrm{H} 4 \mathrm{c}$ & 43.1 & $1.25 \mathrm{E}-17$ & -5.4 \\
\hline NPR3 & natriuretic peptide receptor 3 & 38.2 & $1.37 \mathrm{E}-39$ & -5.3 \\
\hline STC1 & stanniocalcin 1 & 33.8 & $1.27 \mathrm{E}-27$ & -5.1 \\
\hline ACKR1 & $\begin{array}{l}\text { atypical chemokine receptor } 1 \text { (Duffy } \\
\text { blood group) }\end{array}$ & 23.2 & $2.59 \mathrm{E}-28$ & -4.5 \\
\hline IGFBP5 & $\begin{array}{l}\text { insulin-like growth factor binding protein } \\
5\end{array}$ & 14.1 & $2.92 \mathrm{E}-14$ & -3.8 \\
\hline SLC2A3 & $\begin{array}{l}\text { solute carrier family } 2 \text { (facilitated } \\
\text { glucose transporter), member } 3\end{array}$ & 7.9 & 3.69E-28 & -2.3 \\
\hline ODF3B & outer dense fiber of sperm tails $3 B$ & 7.6 & $5.23 \mathrm{E}-20$ & -2.9 \\
\hline ZC3H6 & zinc finger CCCH-type containing 6 & 6.2 & $2.58 \mathrm{E}-28$ & -2.6 \\
\hline INHBA & inhibin, beta $A$ & 6.2 & $7.01 \mathrm{E}-38$ & -2.6 \\
\hline IGF2 & $\begin{array}{l}\text { insulin-like growth factor } 2 \\
\text { (somatomedin } A)\end{array}$ & 5.7 & $2.94 \mathrm{E}-38$ & -2.5 \\
\hline
\end{tabular}

and tight junction accessory genes are expressed i.e. claudin 3 and 5 (CLDN3, CLDN5), occludin (OCLN), tight junction protein 1 and 2 (TJP1, TJP2) etc. However, their expression is not necessarily increased upon presence of brain pericytes (Fig. 5). The expression pattern of endothelial cell marker genes CD34, C-type lectin domain family 14, member A (CLEC14A), von Willebrand factor (VWF) and nitric oxide synthase (NOS3) at 24 to $96 \mathrm{~h}$ shows an increased expression of VWF, a decreased expression of CLEC14A and NOS3 and a steady state for CD34, at least for the coculture with bovine pericytes (Fig. 5). These genes are known endothelial marker genes and are known to be expressed in different type of ECs [6].

\section{Influence of pericytes on signaling pathways in brain-like endothelial cells}

The GO enrichment analysis identified a number of significantly different gene clusters for soloculture conditions vs. coculture conditions. The number of significant gene clusters per assigned ontology, i.e. molecular function, cellular component and biological process were identified. 
Table 3 (continued)

\begin{tabular}{|c|c|c|c|c|}
\hline Gene & Gene description & $\begin{array}{c}\text { Ratio } \\
\text { CBP/Solo }\end{array}$ & p-value & $\log 2 \mathrm{FC}$ \\
\hline INMT & indolethylamine $N$-methyltransferase & 9.2 & $6.93 \mathrm{E}-11$ & -3.2 \\
\hline NPW & neuropeptide $W$ & 4.9 & $1.33 \mathrm{E}-15$ & -2.3 \\
\hline ACKR1 & $\begin{array}{l}\text { atypical chemokine receptor } 1 \text { (Duffy } \\
\text { blood group) }\end{array}$ & 4.7 & $2.18 \mathrm{E}-09$ & -2.2 \\
\hline IGFBP1 & insulin-like growth factor binding protein & 3.7 & $3.75 \mathrm{E}-08$ & -1.9 \\
\hline CCL23 & chemokine (C-C motif) ligand 23 & 3.7 & $5.92 \mathrm{E}-07$ & -1.9 \\
\hline IL1RL1 & interleukin 1 receptor-like 1 & 3.0 & $3.02 \mathrm{E}-42$ & -1.6 \\
\hline LIPG & lipase, endothelial & 2.7 & $2.19 \mathrm{E}-05$ & -1.4 \\
\hline TMEM100 & transmembrane protein 100 & 2.5 & $1.81 \mathrm{E}-03$ & -1.3 \\
\hline ANGPTL4 & angiopoietin-like 4 & 2.5 & $5.92 \mathrm{E}-15$ & -1.3 \\
\hline SELP & $\begin{array}{l}\text { selectin } P \text { (granule membrane protein } \\
140 \mathrm{kDa} \text {, antigen } C D 62 \text { ) }\end{array}$ & 2.5 & $1.86 \mathrm{E}-13$ & -1.3 \\
\hline$\overline{\mathrm{ACKR} 1}$ & $\begin{array}{l}\text { atypical chemokine receptor } 1 \text { (Duffy } \\
\text { blood group) }\end{array}$ & 12.6 & $4.88 \mathrm{E}-18$ & -3.7 \\
\hline INMT & indolethylamine $N$-methyltransferase & 12.3 & $3.63 \mathrm{E}-22$ & -3.6 \\
\hline CADM3 & cell adhesion molecule 3 & 7.3 & $2.08 \mathrm{E}-15$ & -2.9 \\
\hline PTP4A3 & $\begin{array}{l}\text { protein tyrosine phosphatase type IVA, } \\
\text { member } 3\end{array}$ & 5.3 & $2.29 \mathrm{E}-13$ & -2.4 \\
\hline NOTCH3 & notch 3 & 4.9 & $1.02 \mathrm{E}-14$ & -2.3 \\
\hline SOCS3 & suppressor of cytokine signaling 3 & 4.9 & $4.70 \mathrm{E}-31$ & -2.3 \\
\hline PIM1 & $\begin{array}{l}\text { Pim-1 proto-oncogene, serine/threonine } \\
\text { kinase }\end{array}$ & 4.9 & $1.56 \mathrm{E}-12$ & -2.3 \\
\hline SLC2A3 & $\begin{array}{l}\text { solute carrier family } 2 \text { (facilitated } \\
\text { glucose transporter), member } 3\end{array}$ & 4.7 & $5.79 \mathrm{E}-14$ & -2.2 \\
\hline ANGPTL4 & angiopoietin-like 4 & 4.6 & $1.38 \mathrm{E}-35$ & -2.2 \\
\hline CDH15 & $\begin{array}{l}\text { cadherin 15, type 1, M-cadherin } \\
\text { (myotubule) }\end{array}$ & 4.5 & $4.76 \mathrm{E}-07$ & -2.2 \\
\hline MCHR1 & $\begin{array}{l}\text { melanin-concentrating hormone receptor } \\
1\end{array}$ & 53.0 & $1.70 \mathrm{E}-19$ & -5.7 \\
\hline ACKR1 & $\begin{array}{l}\text { atypical chemokine receptor } 1 \text { (Duffy } \\
\text { blood group) }\end{array}$ & 29.1 & $2.85 \mathrm{E}-30$ & -4.9 \\
\hline NPR3 & natriuretic peptide receptor 3 & 22.9 & $3.59 \mathrm{E}-24$ & -4.5 \\
\hline CADM3 & cell adhesion molecule 3 & 8.6 & $1.21 \mathrm{E}-15$ & -3.1 \\
\hline INMT & indolethylamine $N$-methyltransferase & 7.9 & $4.20 \mathrm{E}-16$ & -3.0 \\
\hline SLC2A3 & $\begin{array}{l}\text { solute carrier family } 2 \text { (facilitated } \\
\text { glucose transporter), member } 3\end{array}$ & 7.8 & $1.06 \mathrm{E}-25$ & -2.3 \\
\hline SOCS3 & suppressor of cytokine signaling 3 & 6.2 & $1.38 \mathrm{E}-42$ & -2.6 \\
\hline IGFBP1 & insulin-like growth factor binding protein & 5.7 & $1.58 \mathrm{E}-13$ & -2.5 \\
\hline FBLN2 & fibulin 2 & 5.5 & $3.46 \mathrm{E}-32$ & -2.5 \\
\hline $\mathrm{AK} 4$ & adenylate kinase 4 & 5.2 & $8.13 \mathrm{E}-15$ & -2.4 \\
\hline
\end{tabular}

Shading colour highlights coculture enriched genes that are identified to be in the top 10 of two (light grey) or all time points (dark grey)Shading colour highlights coculture enriched genes that are identified to be in the top 10 of two (light grey) or all time points (dark grey)

Molecular function describes and represents activities rather than entities that occur at the molecular level, such as RNA binding and cytokine binding. A cellular component consists of a component of a cell, that is inherently part of a larger object, such as the ribosome and endoplasmic reticulum. The last ontology parameter represents a biological process and defines a series of events by one or more groups of molecular functions, such as the Wnt signaling pathway and protein folding.

Our results indicate very similar numbers of significant pathways or gene clusters over time for each of the comparisons. 
Table 4 Overlapping soloculture enriched genes (ratio $\geq 2$ ) at 24 h (top), 48 h (middle) and 96 h (bottom) identified in both comparisons i.e. soloculture vs. coculture with human pericytes (CHP) and soloculture vs. coculture with bovine pericytes (CBP)

\begin{tabular}{|c|c|c|c|}
\hline "Gene & Gene description & $\overline{\text { Gene }}$ & Gene description \\
\hline \multicolumn{4}{|c|}{24 hours } \\
\hline ARL4C & $\begin{array}{l}\text { ADP-ribosylation factor-like } \\
4 C\end{array}$ & IL32 & interleukin 32 \\
\hline CREB5 & $\begin{array}{l}c A M P \text { responsive element } \\
\text { binding protein } 5\end{array}$ & IL4I1 & interleukin 4 induced 1 \\
\hline DCAF12L1 & $\begin{array}{l}\text { DDBI and CULA associated } \\
\text { factor } 12 \text {-like } 1\end{array}$ & PLA2G4C & $\begin{array}{l}\text { phospholipase A2, group IVC } \\
\text { (cytosolic, calcium- } \\
\text { independent) }\end{array}$ \\
\hline DUSP8 & $\begin{array}{l}\text { dual specificity phosphatase } \\
\text { dus }\end{array}$ & TGFB2 & $\begin{array}{l}\text { transforming growth factor, } \\
\text { beta } 2\end{array}$ \\
\hline EGR1 & early growth response 1 & VCAM1 & $\begin{array}{l}\text { vascular cell adhesion } \\
\text { molecule } 1\end{array}$ \\
\hline \multicolumn{4}{|c|}{48 hours } \\
\hline$\overline{\mathrm{ABCB} 1}$ & $\begin{array}{l}\text { ATP-binding cassette, sub- } \\
\text { family } B(M D R / T A P), \\
\text { member } 1\end{array}$ & HAS2 & hyaluronan synthase 2 \\
\hline ALG14 & $\begin{array}{l}\text { ALG14, UDP-N- } \\
\text { acetylglucosaminyltransferas } \\
\text { e subunit }\end{array}$ & HIST1H2AC & histone cluster $1, \mathrm{H} 2 \mathrm{ac}$ \\
\hline BAMBI & $\begin{array}{l}\text { BMP and activin membrane- } \\
\text { bound inhibitor }\end{array}$ & HIST1H2BD & histone cluster $1, \mathrm{H} 2 \mathrm{bd}$ \\
\hline BMPER & $\begin{array}{l}\text { BMP binding endothelial } \\
\text { regulator }\end{array}$ & HTR2B & $\begin{array}{l}\text { killer cell lectin-like receptor } \\
\text { subfamily } G, \text { member } 1\end{array}$ \\
\hline CCL14 & $\begin{array}{l}\text { chemokine (C-C motif) } \\
\text { ligand } 14\end{array}$ & ID2 & $\begin{array}{l}\text { inhibitor of DNA binding } 2 \text {, } \\
\text { dominant negative helix- } \\
\text { loop-helix protein }\end{array}$ \\
\hline CDH1 1 & $\begin{array}{l}\text { cadherin 11, type 2, OB- } \\
\text { cadherin (osteoblast) }\end{array}$ & PDGFD & $\begin{array}{l}\text { platelet derived growth } \\
\text { factor } D\end{array}$ \\
\hline CNBD2 & $\begin{array}{l}\text { cyclic nucleotide binding } \\
\text { domain containing } 2\end{array}$ & PLAT & plasminogen activator, tissue \\
\hline CRHBP & $\begin{array}{l}\text { corticotropin releasing } \\
\text { hormone binding protein }\end{array}$ & PTPRD & $\begin{array}{l}\text { protein tyrosine phosphatase, } \\
\text { receptor type, } D\end{array}$ \\
\hline CRISPLD1 & $\begin{array}{l}\text { cysteine-rich secretory } \\
\text { protein LCCL domain } \\
\text { containing } 1\end{array}$ & SESN3 & sestrin 3 \\
\hline EPHX4 & epoxide hydrolase 4 & SLC25A4 & $\begin{array}{l}\text { solute carrier family } 25 \\
\text { (mitochondrial carrier; } \\
\text { adenine nucleotide } \\
\text { translocator), member } 4\end{array}$ \\
\hline FABP4 & $\begin{array}{l}\text { fatty acid binding protein } 4 \text {, } \\
\text { adipocyte }\end{array}$ & SLC40A1 & $\begin{array}{l}\text { solute carrier family } 40 \\
\text { (iron-regulated transporter), } \\
\text { member } 1\end{array}$ \\
\hline FABP5 & $\begin{array}{l}\text { fatty acid binding protein } 5 \text {, } \\
\text { adipocyte }\end{array}$ & STEAP1 & $\begin{array}{l}\text { six transmembrane epithelial } \\
\text { antigen of the prostate } 1\end{array}$ \\
\hline FLRT2 & $\begin{array}{l}\text { fibronectin leucine rich } \\
\text { transmembrane protein } 2\end{array}$ & SYNM & $\begin{array}{l}\text { synemin, intermediate } \\
\text { filament protein }\end{array}$ \\
\hline GDF3 & $\begin{array}{l}\text { growth differentiation factor } \\
3\end{array}$ & TM4SF18 & $\begin{array}{l}\text { transmembrane } 4 \text { L six } \\
\text { family member } 18\end{array}$ \\
\hline GJA4 & $\begin{array}{l}\text { gap junction protein, alpha } \\
4,37 k D a\end{array}$ & TRIM16 & tripartite motif containing 16 \\
\hline GJA5 & $\begin{array}{l}\text { gap junction protein, alpha } \\
5,40 k D a\end{array}$ & TSPAN7 & tetraspanin 7 \\
\hline GUCY1A3 & $\begin{array}{l}\text { guanylate cyclase 1, soluble, } \\
\text { alpha } 3\end{array}$ & ZNF326 & zinc finger protein 326 \\
\hline
\end{tabular}




\begin{tabular}{|c|c|c|c|}
\hline \multicolumn{4}{|c|}{96 hours } \\
\hline ACP5 & $\begin{array}{l}\text { acid phosphatase 5, tartrate } \\
\text { resistant }\end{array}$ & IFIT3 & $\begin{array}{l}\text { interferon-induced protein } \\
\text { with tetratricopeptide repeats } \\
3\end{array}$ \\
\hline ACSM3 & $\begin{array}{l}\text { acyl-CoA synthetase } \\
\text { medium-chain family } \\
\text { member } 3\end{array}$ & IL32 & interleukin 32 \\
\hline AMDHD2 & $\begin{array}{l}\text { amidohydrolase domain } \\
\text { containing } 2\end{array}$ & IL4I1 & interleukin 4 induced 1 \\
\hline $\mathrm{AMH}$ & anti-Mullerian hormone & KIFC1 & kinesin family member $C 1$ \\
\hline AP4S1 & $\begin{array}{l}\text { adaptor-related protein } \\
\text { complex } 4 \text {, sigma } 1 \text { subunit }\end{array}$ & KLRK1 & $\begin{array}{l}\text { killer cell lectin-like receptor } \\
\text { subfamily } K, \text { member } 1\end{array}$ \\
\hline ARL4C & $\begin{array}{l}A D P \text {-ribosylation factor-like } \\
4 C\end{array}$ & LFNG & $\begin{array}{l}\text { LFNG O-fucosylpeptide } 3 \text { - } \\
\text { beta-N- } \\
\text { acetylglucosaminyltransferas } \\
e\end{array}$ \\
\hline ATAD3B & $\begin{array}{l}\text { ATPase family, AAA domain } \\
\text { containing } 3 B\end{array}$ & MMP10 & $\begin{array}{l}\text { matrix metallopeptidase } 10 \\
\text { (stromelysin 2) }\end{array}$ \\
\hline АTOH8 & $\begin{array}{l}\text { atonal homolog } 8 \\
\text { (Drosophila) }\end{array}$ & MT1E & metallothionein $1 E$ \\
\hline ATP2A3 & $\begin{array}{l}\text { ATPase, Ca++ transporting, } \\
\text { ubiquitous }\end{array}$ & MT1X & metallothionein $1 X$ \\
\hline BMPER & $\begin{array}{l}\text { BMP binding endothelial } \\
\text { regulator }\end{array}$ & MYBL2 & $\begin{array}{l}\text { v-myb avian myeloblastosis } \\
\text { viral oncogene homolog-like } \\
2\end{array}$ \\
\hline CDH1 1 & $\begin{array}{l}\text { cadherin } 11 \text {, type } 2, O B- \\
\text { cadherin (osteoblast) }\end{array}$ & NOS1 & $\begin{array}{l}\text { nitric oxide synthase } 1 \\
\text { (neuronal) }\end{array}$ \\
\hline CENPM & centromere protein $M$ & NR4A1 & $\begin{array}{l}\text { nuclear receptor subfamily } 4 \text {, } \\
\text { group } A \text {, member } 1\end{array}$ \\
\hline & oxidase assembly factor & & \\
\hline CREB5 & $\begin{array}{l}c A M P \text { responsive element } \\
\text { binding protein } 5\end{array}$ & PLA2G4C & $\begin{array}{l}\text { phospholipase A2, group IVC } \\
\text { (cytosolic, calcium- } \\
\text { independent) }\end{array}$ \\
\hline CRHBP & $\begin{array}{l}\text { corticotropin releasing } \\
\text { hormone binding protein }\end{array}$ & POSTN & $\begin{array}{l}\text { periostin, osteoblast specific } \\
\text { factor }\end{array}$ \\
\hline CYP1A1 & $\begin{array}{l}\text { cytochrome P450, family } 1 \text {, } \\
\text { subfamily A, polypeptide } 1\end{array}$ & PRKCD & protein kinase $C$, delta \\
\hline DCBLD2 & $\begin{array}{l}\text { discoidin, } C U B \text { and } L C C L \\
\text { domain containing } 2\end{array}$ & RAMP2 & $\begin{array}{l}\text { receptor }(G \text { protein-coupled }) \\
\text { activity modifying protein } 2\end{array}$ \\
\hline DDX39A & $\begin{array}{l}\text { DEAD (Asp-Glu-Ala-Asp) } \\
\text { box polypeptide } 39 A\end{array}$ & RASGRP3 & $\begin{array}{l}R A S \text { guanyl releasing protein } \\
3 \text { (calcium and } D A G- \\
\text { regulated) }\end{array}$ \\
\hline EGR1 & early growth response 1 & SEMA3G & $\begin{array}{l}\text { sema domain, } \\
\text { immunoglobulin domain (Ig), } \\
\text { short basic domain, secreted, } \\
\text { (semaphorin) } 3 G\end{array}$ \\
\hline EGR3 & early growth response 3 & SESN3 & sestrin 3 \\
\hline EHD3 & EH-domain containing 3 & SLC25A34 & $\begin{array}{l}\text { solute carrier family } 25 \text {, } \\
\text { member } 34\end{array}$ \\
\hline EPHB1 & EPH receptor $B 1$ & SPAG5 & sperm associated antigen 5 \\
\hline EPS8L1 & EPS8-like 1 & STMN1 & Stathmin 1 \\
\hline
\end{tabular}

Tables 6 and 7 list the top solo- and coculture enriched pathways per comparison and per time point identified by the GO enrichment tool. Pathways were enriched if $\mathrm{p}<0.05$ and when the number of significant upregulated genes was at least 1.5 times upregulated in the solo- or coculture condition. 
Table 4 (continued)

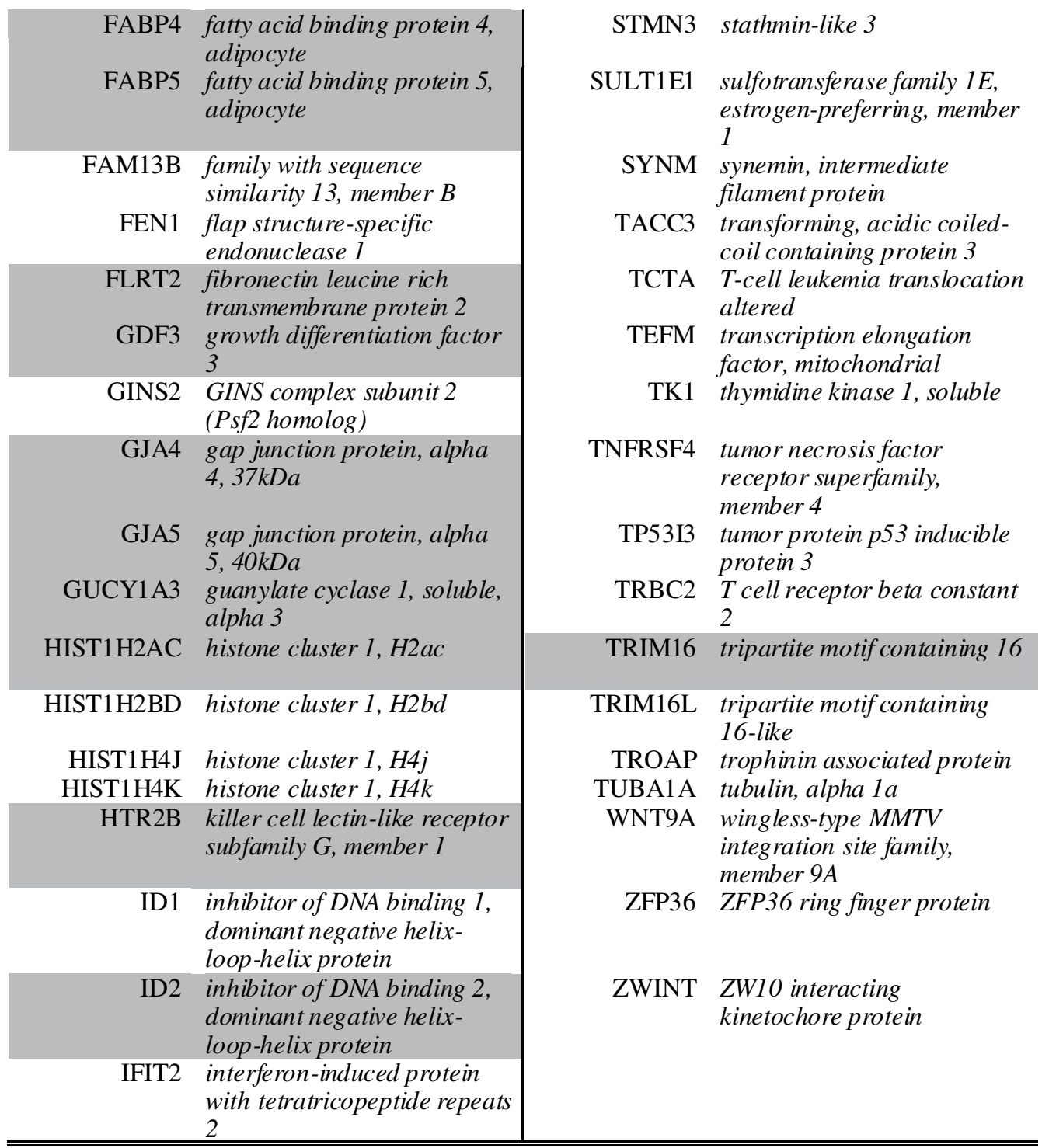

Shading colour highlights soloculture enriched genes that are identified to be overlapping in two (light grey) or all time points (dark grey)

Table 8, 9, 10 and 11 list several top regulated significant pathways or gene clusters per comparison and per time point (i.e. 24 and $96 \mathrm{~h}$ ) that were identified by using the KOBAS software, thereby focusing on databases like Panther, KEGG and Reactome [37].

Besides a general analysis of the number of differentially expressed pathways, analysis was performed for specific gene clusters or pathways that are known to relate to $\mathrm{BBB}$ induction, maturation or maintenance (Fig. 7). Other gene clusters like those for transferrin transport, organic acid transport, anion transport and L-amino acid transport did not show any significant difference between the solo- and coculture (data not shown). Our results show a general high variability in differential expression over time, indicating the importance of time.

An interesting cluster of genes is the one related to the regulation of membrane permeability. The latter is significantly enriched in the soloculture compared to $\mathrm{CHP}$ at $24 \mathrm{~h}$, after which significance is lost (at $48 \mathrm{~h}$ and $96 \mathrm{~h}$ ), although the soloculture shows a general upregulation. For the comparison between the soloculture and CBP, this cluster of genes related to the regulation of membrane permeability, is the only cluster of genes in this graph that is enriched for the soloculture. This indicates that the genes that significantly differ are upregulated in the soloculture. The cluster of genes related 
Table 5 Overlapping coculture enriched genes (ratio $\geq 2$ ) at 24 h (top), 48 h (middle) and 96 h (bottom) identified in both comparisons i.e. soloculture vs. coculture with human pericytes (CHP) and soloculture vs. coculture with bovine pericytes (CBP)

\begin{tabular}{|c|c|c|c|}
\hline Gene & Gene description & Gene & Gene description \\
\hline \multicolumn{4}{|c|}{24 hours } \\
\hline$\overline{\mathrm{ACKR}}$ & $\begin{array}{l}\text { atypical chemokine receptor } \\
1 \text { (Duffy blood group) }\end{array}$ & MMP1 & $\begin{array}{l}\text { matrix metallopeptidase } 1 \\
\text { (interstitial collagenase) }\end{array}$ \\
\hline CCL23 & $\begin{array}{l}\text { chemokine ( } C \text {-C motif) } \\
\text { ligand } 23\end{array}$ & MSMP & $\begin{array}{l}\text { microseminoprotein, prostate } \\
\text { associated }\end{array}$ \\
\hline ETV4 & ets variant 4 & NPW & neuropeptide W \\
\hline IL1RL1 & interleukin 1 receptor-like 1 & SELP & $\begin{array}{l}\text { selectin } P \text { (granule membrane } \\
\text { protein } 140 \mathrm{kDa} \text {, antigen } \\
\text { CD62) }\end{array}$ \\
\hline INMT & $\begin{array}{l}\text { indolethylamine } N \text { - } \\
\text { methyltransferase }\end{array}$ & SLCO2A1 & $\begin{array}{l}\text { solute carrier organic anion } \\
\text { transporter family, member } \\
2 \mathrm{Al}\end{array}$ \\
\hline LIPG & lipase, endothelial & SOCS3 & $\begin{array}{l}\text { suppressor of cytokine } \\
\text { signaling } 3\end{array}$ \\
\hline MGP & matrix Gla protein & TXNIP & thioredoxin interacting protein \\
\hline \multicolumn{4}{|c|}{48 hours } \\
\hline$\overline{\mathrm{ACKR} 1}$ & $\begin{array}{l}\text { atypical chemokine receptor } \\
1 \text { (Duffy blood group) }\end{array}$ & LITAF & $\begin{array}{l}\text { lipopolysaccharide-induced } \\
\text { TNF factor }\end{array}$ \\
\hline ADAMTS1 & $\begin{array}{l}\text { ADAM metallopeptidase with } \\
\text { thrombospondin type } 1 \text { motif, } \\
1\end{array}$ & MACROD1 & MACRO domain containing 1 \\
\hline ADSSL1 & $\begin{array}{l}\text { adenylosuccinate synthase } \\
\text { like } 1\end{array}$ & MAP3 K6 & $\begin{array}{l}\text { mitogen-activated protein } \\
\text { kinase kinase kinase } 6\end{array}$ \\
\hline AK4 & adenylate kinase 4 & NAT6 & $\begin{array}{l}N \text {-acetyltransferase } 6(\text { GCN5- } \\
\text { related) }\end{array}$ \\
\hline ALDOC & $\begin{array}{l}\text { aldolase } C, \text { fructose- } \\
\text { bisphosphate }\end{array}$ & NOTCH3 & notch 3 \\
\hline ANGPTL4 & angiopoietin-like 4 & ODF3B & $\begin{array}{l}\text { outer dense fiber of sperm tails } \\
3 B\end{array}$ \\
\hline APOBEC3D & $\begin{array}{l}\text { apolipoprotein } B \text { mRNA } \\
\text { editing enzyme, catalytic } \\
\text { polypeptide-like } 3 D\end{array}$ & OPRL1 & opiate receptor-like 1 \\
\hline ASS1 & argininosuccinate synthase 1 & PIM1 & $\begin{array}{l}\text { Pim-1 proto-oncogene, } \\
\text { serine/threonine kinase }\end{array}$ \\
\hline CACNG6 & $\begin{array}{l}\text { calcium channel, voltage- } \\
\text { dependent, gamma subunit } 6\end{array}$ & PITPNM1 & $\begin{array}{l}\text { phosphatidylinositol transfer } \\
\text { protein, membrane-associated } \\
1\end{array}$ \\
\hline CADMB & cell adhesion molecule 3 & PLEKHA4 & $\begin{array}{l}\text { pleckstrin homology domain } \\
\text { containing, family A } \\
\text { (phosphoinositide binding } \\
\text { specific) member } 4\end{array}$ \\
\hline $\mathrm{CDH} 4$ & $\begin{array}{l}\text { cadherin } 4 \text {, type } 1, R- \\
\text { cadherin (retinal) }\end{array}$ & PTP4A3 & $\begin{array}{l}\text { protein tyrosine phosphatase } \\
\text { type IVA, member } 3\end{array}$ \\
\hline $\mathrm{CFB}$ & complement factor $B$ & RASSF4 & $\begin{array}{l}\text { Ras association (RalGDS/AF- } \\
\text { 6) domain family member } 4\end{array}$ \\
\hline CPLX1 & complexin 1 & RCN3 & $\begin{array}{l}\text { reticulocalbin } 3, \text { EF-hand } \\
\text { calcium binding domain }\end{array}$ \\
\hline EML2 & $\begin{array}{l}\text { echinoderm microtubule } \\
\text { associated protein like } 2\end{array}$ & RHOU & ras homolog family member $U$ \\
\hline ETV4 & ets variant 4 & RIN1 & Ras and Rab interactor 1 \\
\hline
\end{tabular}


Table 5 (continued)

FLNC filamin C, gamma
FLT1 fms-related tyrosine kinase 1

\begin{tabular}{|c|c|}
\hline GABBR2 & $\begin{array}{l}\text { gamma-aminobutyric acid } \\
(G A B A) \text { B receptor, } 2\end{array}$ \\
\hline GALNT15 & $\begin{array}{l}\text { polypeptide } N \text { - } \\
\text { acetylgalactosaminyltransfer } \\
\text { ase } 15\end{array}$ \\
\hline GRIN2D & $\begin{array}{l}\text { glutamate receptor, } \\
\text { ionotropic, } N \text {-methyl D- } \\
\text { aspartate } 2 D\end{array}$ \\
\hline HSPB6 & $\begin{array}{l}\text { heat shock protein, alpha- } \\
\text { crystallin-related, B6 }\end{array}$ \\
\hline IGF2 & $\begin{array}{l}\text { insulin-like growth factor } 2 \\
\text { (somatomedin A) }\end{array}$ \\
\hline INHBA & inhibin, beta $A$ \\
\hline ITGE & integrin, beta 4 \\
\hline JAK & Janus kinase 3 \\
\hline
\end{tabular}

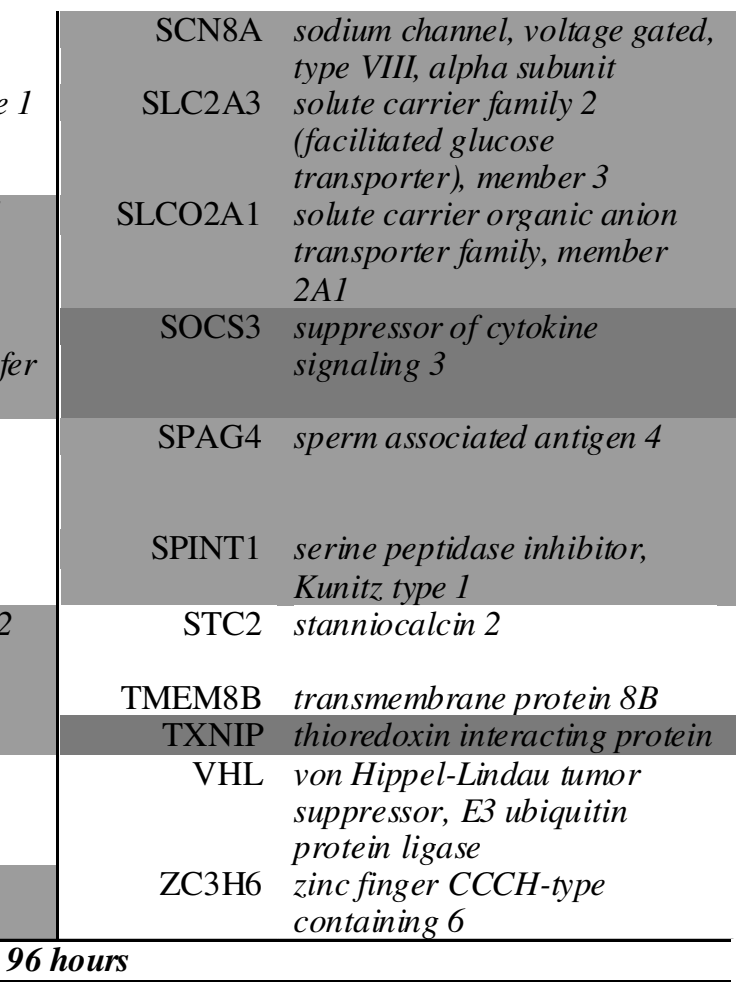

\begin{tabular}{|c|c|c|c|}
\hline ACKR1 & $\begin{array}{l}\text { atypical chemokine receptor } \\
1 \text { (Duffy blood group) }\end{array}$ & KCNN3 & $\begin{array}{l}\text { potassium intermediate/small } \\
\text { conductance calcium-activated } \\
\text { channel, subfamily } N \text {, member } \\
3\end{array}$ \\
\hline ADAMTS4 & $\begin{array}{l}\text { ADAM metallopeptidase with } \\
\text { thrombospondin type } 1 \text { motif, } \\
4\end{array}$ & ITGB4 & integrin, beta 4 \\
\hline ADSSL1 & $\begin{array}{l}\text { adenylosuccinate synthase } \\
\text { like } 1\end{array}$ & LAMP3 & $\begin{array}{l}\text { lysosomal-associated } \\
\text { membrane protein } 3\end{array}$ \\
\hline AK4 & adenylate kinase 4 & MACROD1 & MACRO domain containing 1 \\
\hline ALDH1 A3 & $\begin{array}{l}\text { aldehyde dehydrogenase } 1 \\
\text { family, member A3 }\end{array}$ & MS4A6A & $\begin{array}{l}\text { membrane-spanning } 4- \\
\text { domains, subfamily } A \text {, member } \\
6 A\end{array}$ \\
\hline ALDOC & $\begin{array}{l}\text { aldolase } C \text {, fructose- } \\
\text { bisphosphate }\end{array}$ & MSMP & $\begin{array}{l}\text { microseminoprotein, prostate } \\
\text { associated }\end{array}$ \\
\hline ANGPTL4 & angiopoietin-like 4 & NOTCH3 & notch 3 \\
\hline BDNF & $\begin{array}{l}\text { brain-derived neurotrophic } \\
\text { factor }\end{array}$ & NPR3 & natriuretic peptide receptor 3 \\
\hline CFB & complement factor $B$ & P4HA1 & $\begin{array}{l}\text { prolyl 4-hydroxylase, alpha } \\
\text { polypeptide I }\end{array}$ \\
\hline COL6A2 & collagen, type VI, alpha 2 & PDE3A & $\begin{array}{l}\text { phosphodiesterase } 3 A, c G M P \text { - } \\
\text { inhibited }\end{array}$ \\
\hline CPLX1 & complexin 1 & PDIA5 & $\begin{array}{l}\text { protein disulfide isomerase } \\
\text { family A, member } 5\end{array}$ \\
\hline EML2 & $\begin{array}{l}\text { echinoderm microtubule } \\
\text { associated protein like } 2\end{array}$ & PDLIM1 & PDZ and LIM domain 1 \\
\hline ETV4 & ets variant 4 & PIM1 & $\begin{array}{l}\text { Pim-1 proto-oncogene, } \\
\text { serine/threonine kinase }\end{array}$ \\
\hline
\end{tabular}


Table 5 (continued)

\begin{tabular}{|c|c|c|c|}
\hline FBLN2 & fibulin 2 & PRKAA2 & $\begin{array}{l}\text { protein kinase, AMP-activated, } \\
\text { alpha } 2 \text { catalytic subunit }\end{array}$ \\
\hline GABBR2 & \multirow{2}{*}{$\begin{array}{l}\text { gamma-aminobutyric acid } \\
\text { (GABA) B receptor, } 2 \\
\text { polypeptide } N \text { - } \\
\text { acetylgalactosaminyltransfer } \\
\text { ase } 15\end{array}$} & RAB3C & $\begin{array}{l}\text { RAB3C, member RAS } \\
\text { oncogene family }\end{array}$ \\
\hline GALN15 & & RASSF4 & $\begin{array}{l}\text { Ras association (RalGDS/AF- } \\
6 \text { ) domain family member } 4\end{array}$ \\
\hline HMGN5 & $\begin{array}{l}\text { high mobility group } \\
\text { nucleosome binding domain } \\
5\end{array}$ & RHOU & ras homolog family member $U$ \\
\hline HOXB8 & homeobox B8 & SCN8A & $\begin{array}{l}\text { sodium channel, voltage gated, } \\
\text { type VIII, alpha subunit }\end{array}$ \\
\hline HSP90B1 & $\begin{array}{l}\text { heat shock protein 90kDa } \\
\text { beta (Grp94), member } 1\end{array}$ & SELP & $\begin{array}{l}\text { selectin } P \text { (granule membrane } \\
\text { protein } 140 \mathrm{kDa} \text {, antigen } \\
\text { CD62) }\end{array}$ \\
\hline HSPA5 & $\begin{array}{l}\text { heat shock } 70 k D a \text { protein } 5 \\
\text { (glucose-regulated protein, } \\
78 k D a)\end{array}$ & SERPING1 & $\begin{array}{l}\text { serpin peptidase inhibitor, } \\
\text { clade } G(C 1 \text { inhibitor }), \\
\text { member } 1\end{array}$ \\
\hline HSPB6 & $\begin{array}{l}\text { heat shock protein, alpha- } \\
\text { crystallin-related, B6 }\end{array}$ & SLC2A3 & $\begin{array}{l}\text { solute carrier family } 2 \\
\text { (facilitated glucose } \\
\text { transporter), member } 3\end{array}$ \\
\hline HTR1D & $\begin{array}{l}\text { 5-hydroxytryptamine } \\
\text { (serotonin) receptor } 1 D, G \\
\text { protein-coupled }\end{array}$ & SLC46A3 & $\begin{array}{l}\text { solute carrier family } 46 \text {, } \\
\text { member } 3\end{array}$ \\
\hline IFITM2 & $\begin{array}{l}\text { interferon induced } \\
\text { transmembrane protein } 2\end{array}$ & SOCS3 & $\begin{array}{l}\text { suppressor of cytokine } \\
\text { signaling } 3\end{array}$ \\
\hline IGF2 & $\begin{array}{l}\text { insulin-like growth factor } 2 \\
\text { (somatomedin A) }\end{array}$ & SPAG4 & sperm associated antigen 4 \\
\hline IGFBP1 & $\begin{array}{l}\text { insulin-like growth factor } \\
\text { binding protein } 1\end{array}$ & SPINT1 & $\begin{array}{l}\text { serine peptidase inhibitor, } \\
\text { Kunitz type } 1\end{array}$ \\
\hline INHBA & inhibin, beta $A$ & TXNIP & thioredoxin interacting protein \\
\hline INHBB & inhibin, beta $B$ & ZC3H6 & $\begin{array}{l}\text { zinc finger } C \mathrm{CCH} \text {-type } \\
\text { containing } 6\end{array}$ \\
\hline
\end{tabular}

Shading colour highlights coculture enriched genes that are identified to be overlapping in two (light grey) or all time points (dark grey)

to the $\mathrm{p} 38 /$ mitogen-activated protein kinase (MAPK) pathway is shown to be differentially expressed only at $48 \mathrm{~h}$ after putting ECs into coculture. This pathway is known to promote endothelial cell migration. The gene set related to transforming growth factor (TGF)-b is shown to be differentially expressed for at least some time points in both cocultures.

\section{Discussion}

Influence of brain pericytes on functional barrier properties: Barrier tightness and efflux transporter functionality

The tightening of junctions between human ECs, resulting in a decreased permeability to non-permeant markers, such as LY, is demonstrated to occur when ECs are cultivated with pericytes of either bovine (i.e. primary cells) or human (i.e. cell line) origin. This confirms the contribution of soluble factors secreted by brain pericytes in ECs barrier tightening. Therefore, this in vitro set-up proved to be suitable for investigation of the molecular mechanisms responsible for establishment of this important BBB feature in human ECs by RNA sequencing.

Influence of brain pericytes on the transcriptomic profile of brain-like endothelial cells

Some important mechanisms involved in BBB establishment and maturation, notably the influence of brain pericytes, remain poorly understood. For this, we investigated transcriptional changes in ECs in soloculture compared to in ECs in coculture with brain pericytes.

\section{Influence of pericytes on the global gene expression profile of brain-like endothelial cells}

Compared to the total number of identified genes, only few genes are differentially expressed when comparing 


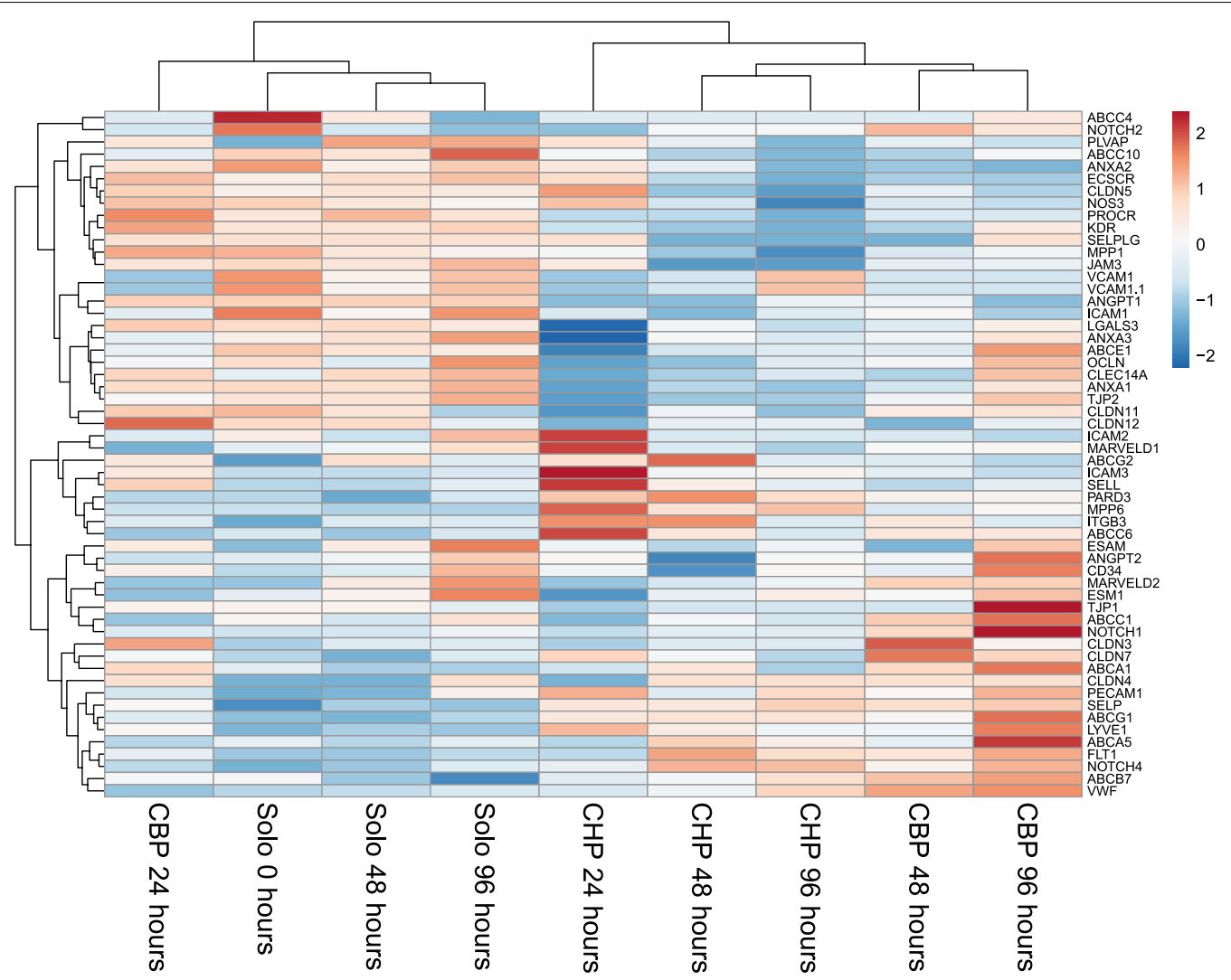

Fig. 5 Heat map of vascular genes, junction associated genes, tight junction and tight junction associated genes, ABC transporter genes and endothelial marker genes in endothelial cells. Data input consisted of the normalized expression in solocultured endothelial cells and the normalized expression in cocultured endothelial cells (i.e. with either human pericytes (CHP) or bovine pericytes (CBP). Unit variance scaling is applied to rows

solocultured and cocultured ECs. This result suggests that only a small percentage of genes is responsible for the observed barrier tightening in ECs. The number of differentially expressed genes between solo- and coculture is increasing with coculture duration. Indeed, this was expected as the EC monolayer was tighter after $96 \mathrm{~h}$ in presence of pericytes than after $24 \mathrm{~h}$.

\section{Enriched gene expression}

The increasing number of soloculture enriched genes over time, while the expression of those genes is not differentially regulated in the soloculture over time, might actually reflect their downregulation in the CBP and CHP. Indeed, the importance of downregulated genes in ECs, as an integral part of the BBB signature, was already pointed out by Daneman et al. [10] while comparing BBB ECs with peripheral ECs in mice.

Although, some differences can be observed in the transcriptomic profile of the two cocultures, these differences might simply reflect the differences between the two cell types (i.e. cell line for human pericytes vs. primary cells for bovine pericytes). Indeed, this was not the scope of our study. However, the fact that some genes are regulated in both cocultures, while compared to soloculture, reinforces the potential importance of those genes in the barrier tightening that was observed in both cocultures.

Although, the role of those genes should be further evaluated using other techniques, some of them were already found to be relevant regarding the BBB in other studies. As an example, the Duffy antigen receptor (ACKR1) is an interesting gene listed in the top 10 of coculture enriched genes for both the CBP and the $\mathrm{CHP}$ at all time points. ACKR1 is a non-specific receptor for several pro-inflammatory chemokines such as the chemokine (C-X-C motif) ligand 2 (CXCL2) [17, 35]. One role of ACKR1 is to retain neutrophil-derived CXCL2 at the endothelial junctions to regulate its unidirectional migration across the venule wall. This has recently been demonstrated by a study of Girbl et al. [17]. However, the reason behind the observed high expression of ACKR1 in cocultured ECs in this study will have to be further 


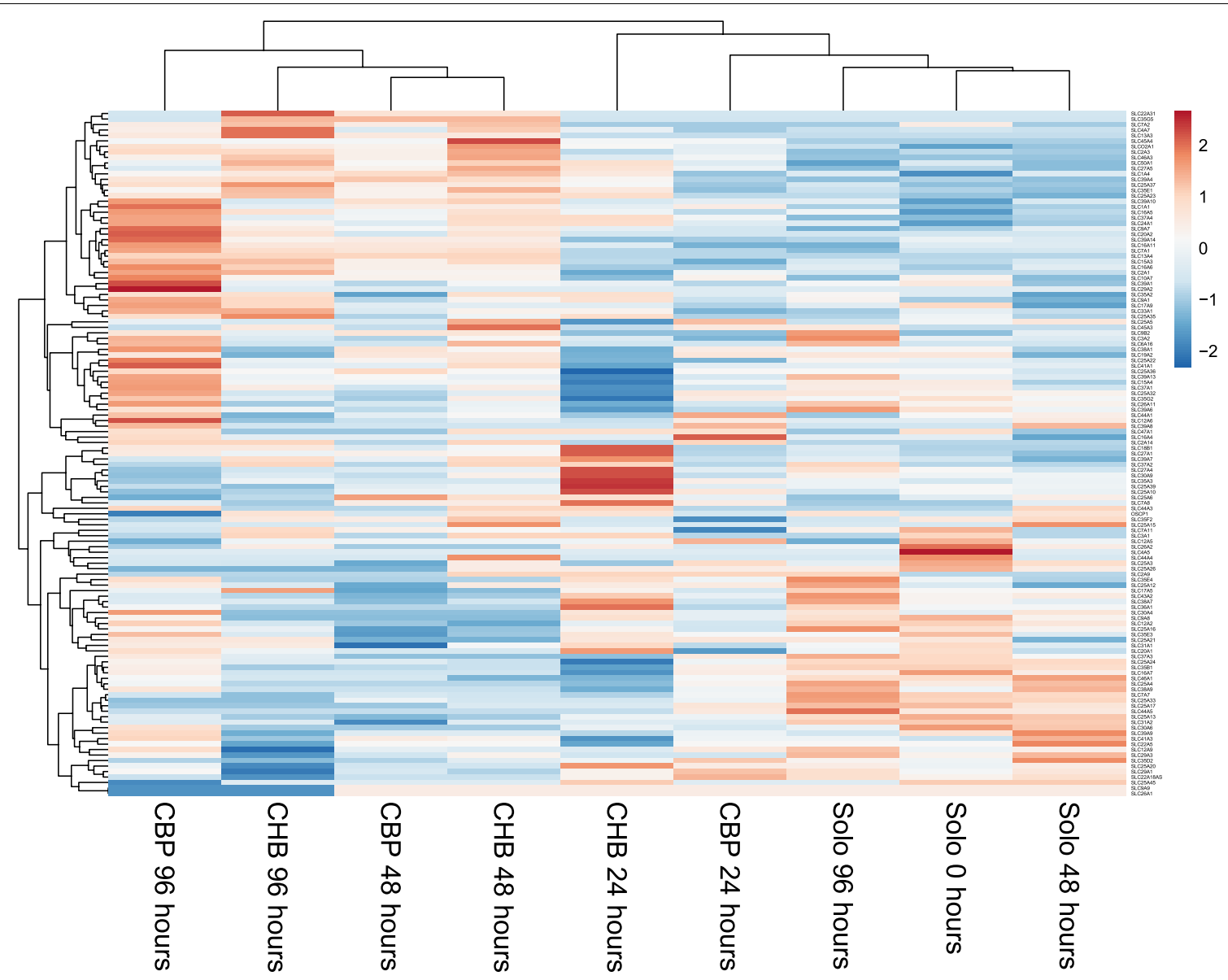

Fig. 6 Heatmap of all expressed solute carrier (SLC) transporters. Data input consisted of the normalized expression in solocultured endothelial cells and the normalized expression in cocultured endothelial cells (i.e. with either human pericytes (CHP) or bovine pericytes (CBP). Unit variance scaling is applied to rows

evaluated. It is likely that this is related to the secretion of CXCL1 by pericytes (and ECs), which on its turn forms a cue for neutrophils that are known to secrete CXCL2 [17].

Another interesting gene is the bone morphogenetic protein endothelial cell precursor-derived regulator (BMPER) which is indicated as a soloculture enriched gene at several time points. The high expression of BMPER in solocultured ECs might be explained by its relation to forkhead box $\mathrm{O} 3 \mathrm{a}$ (FoxO3a), which is a transcription factor involved in the regulation of endothelial permeability [25].

\section{Gene expression profile of specific genes}

The expression of BBB-related genes in ECs is not necessarily depicting the main change upon pericyte induction, as for example genes that are known to increase vascular permeability, e.g. ANGPT2, PLVAP and ICAM1 are demonstrated to be upregulated with a loss of pericytes $[10,22]$. Our data only partially reflects this as only some of these vascular-important genes are decreased, e.g. PLVAP, for which expression decreases drastically from 24 to $48 \mathrm{~h}$ and for ICAM1 and ANGPT1, which are genes known to increase permeability.

Tight junction proteins are important proteins known to regulate $\mathrm{BBB}$ permeability thereby restricting the paracellular pathway $[13,19,20]$. Our results show expression of several important tight junction genes and tight junction-associated genes, however, they are not characterized by a drastic response upon presence of brain pericytes, although some show a visible response e.g. CLDN3, CLDN7, CLDN10. This stipulates the hypothesis explained above of Daneman et al. [10] and confirms results from other studies [14].

Our data does therefore not directly lead to a conclusive explanation that clarifies the observed difference in endothelial permeability for cocultured ECs compared to solocultured ECs, which suggests that the presence of pericytes alone does not define the BBB. 
Table 6 Top regulated soloculture enriched pathways at $24 \mathrm{~h}$ (top), $48 \mathrm{~h}$ (middle) and 96 h (bottom) for (A) the comparison of soloculture vs. coculture with human pericytes (CHP); and for (B) the comparison of soloculture vs. coculture with bovine pericytes (CBP)

A.

\section{$24 \mathrm{~h}$}

Pathway

Post-Golgi vesicle mediated transport

Regulation of programmed cell death

Regulation of cell death

Regulation of apoptotic process

Golgi vesicle transport

Protein folding

Regulation of transcription from RNA polymerase II promotor in response to hypoxia

Negative regulation of cell death

Negative regulation of programmed cell death

De novo protein folding

$48 \mathrm{~h}$

RNA export from nucleus

mRNA export from nucleus

Post-Golgi vesicle-mediated transport

Protein localization to endosome

Type I interferon production

Regulation of type I interferon production

Regulation of monocyte differentiation

Golgi localization

Protein K48-linked ubiquitination

Pyrimidine nucleotide metabolic process

$96 \mathrm{~h}$

Arp2/3 complex-mediated actin nucleation

Pyrimidine nucleoside triphosphate metabolic process

Programmed necrotic cell death

Necroptotic process

sprouting angiogenesis

Regulation of necroptotic process

Fibroblast apoptotic process

Deoxyribonucleotide biosynthetic process

Positive regulation of protein catabolic process

Positive regulation of protein modification by small protein conjugation or removal
B.

$24 \mathrm{~h}$

Pathway

Ratio p-value

Ratio p-value

Regulation of cell morphogenesis involved in differentiation

Salivary gland morphogenesis

Salivary gland development

Lysosomal transport

Establishment of protein localization to plasma membrane

Protein localization to plasma membrane

Positive regulation of osteoblast proliferation

Plasma membrane organization

Toll-like receptor 3 signaling pathway

Exocrine system development

$2.1 \quad 6.90 \mathrm{E}-04$

$1.7 \quad 6.50 \mathrm{E}-06$

$1.7-1.40 \mathrm{E}-05$

$1.8 \quad 1.90 \mathrm{E}-05$

1.7 4.10E-05

$3.8 \quad 4.60 \mathrm{E}-05$

$1.9 \quad 5.40 \mathrm{E}-05$

$1.9 \quad 5.70 \mathrm{E}-05$

$2.0 \quad 6.60 \mathrm{E}-05$ $48 \mathrm{~h}$

$1.5 \quad 2.30 E-05$

RNA splicing, via transesterification reactions

mRNA splicing, via spliceosome

RNA splicing, via transesterification reactions with bulged adenosine

Regulation of cellular protein catabolic process

$3.0 \quad 7.60 \mathrm{E}-04$

$3.0 \quad 1.44 \mathrm{E}-03$

$2.0 \quad 1.72 \mathrm{E}-03$

$3.3 \quad 2.66 \mathrm{E}-03$

$2.0 \quad 2.94 \mathrm{E}-03$

$2.0 \quad 3.27 E-03$

$2.0 \quad 4.00 \mathrm{E}-03$

$1.6 \quad 5.24 \mathrm{E}-03$

$3.0 \quad 5.72 \mathrm{E}-03$

$1.6 \quad 7.00 E-05$

$1.5 \quad 3.40 E-04$

$7.0 \quad 5.80 \mathrm{E}-04$

$1.8 \quad 7.00 \mathrm{E}-04$

Regulation of proteolysis involved in cellular protein catabolic process

$1.8 \quad 7.00 \mathrm{E}-04$

Positive regulation of cellular protein catabolic process

$2.0 \quad 7.60 \mathrm{E}-04$

$2.0 \quad 7.60 \mathrm{E}-04$

$1.6 \quad 1.00 E-03$

mRNA metabolic process

Ribonucleoside triphosphate biosynthetic process

Positive regulation of proteolysis involved in cellular protein catabolic process

$1.8 \quad 1.46 E-03$

mRNA processing

$2.0 \quad 7.50 \mathrm{E}-04$

$1.8 \quad 1.01 \mathrm{E}-03$

$4.5 \quad 1.88 \mathrm{E}-03$

$9.0 \quad 2.59 \mathrm{E}-03$

$5.0 \quad 3.74 \mathrm{E}-03$

$2.0 \quad 3.74 \mathrm{E}-03$

9.20E-08

$4.1 \quad 2.70 E-07$

$4.1 \quad 2.70 E-07$

$1.8 \quad 4.00 E-07$

$1.9 \quad 5.80 E-07$

$2.5 \quad 1.70 \mathrm{E}-06$

$2.2 \quad 2.50 E-06$

$1.6 \quad 2.80 E-06$

$2.7 \quad 3.40 \mathrm{E}-06$

$2.6 \quad 4.20 E-06$

$2.0 \quad 5.23 E-03$
$96 \mathrm{~h}$

Positive regulation of protein ubiquitination

Positive regulation of ligase activity

Positive regulation of protein modification by small protein conjugation or removal

Nucleoside monophosphate metabolic process

Positive regulation of ubiquitin-protein transferase activity

Regulation of protein modification by small protein conjugation or removal

Regulation of protein ubiquitination

Ribonucleoside monophosphate metabolic process

Regulation of ligase activity

Positive regulation of execution phase of apoptosis

2.8

$2.8-1.00 E-05$

$3.9 \quad 1.90 E-05$

$2.6 \quad 2.00 E-05$

$2.2 \quad 2.70 \mathrm{E}-05$

$4.3 \quad 4.40 E-05$

$2.1 \quad 8.00 E-05$

$2.1 \quad 8.60 E-05$

1.9 1.10E-04

$4.0 \quad 2.30 E-04$

$1.8 \quad 5.81 E-03$

Pathways in italic are soloculture enriched pathways identified in both comparisons for that specific time point. The 2 nd column represents the ratio of upregulated and downregulated genes in the pathway under study (ratio $\geq 1.5$ ) 
Table 7 Top 10 regulated coculture enriched pathways at $24 \mathrm{~h}$ (top), $48 \mathrm{~h}$ (middle) and $96 \mathrm{~h}$ (bottom) for (A) the comparison of soloculture vs. coculture with human pericytes (CHP); and for (B) the comparison of soloculture vs. coculture with bovine pericytes (CBP)

A.

\section{$24 \mathrm{~h}$}

Pathway

Formation of translation preinitiation complex

Endoplasmic reticulum calcium ion homeostasis

Porphyrin-containing compound biosynthetic process

Ribonucleoprotein complex assembly

Tetrapyrrole biosynthetic process

Cytoskeleton-dependent cytokinesis

Pigment biosynthetic process

Negative regulation of centrosome duplication

Negative regulation of endoplasmic reticulum cal-

cium ion concentration

Negative regulation of centrosome cycle

$48 \mathrm{~h}$

Notch signaling pathway

Hyaluronan catabolic process

Nuclear-transcribed mRNA poly(A) tail shortening

Formation of translation preinitiation complex

Response to cold

mRNA catabolic process

Autonomic nervous system development

Polysaccharide biosynthetic process

Lipopolysaccharide metabolic process

Lipopolysaccharide biosynthetic process

$96 \mathrm{~h}$

Translational termination

Nuclear-transcribed mRNA catabolic process

Cotranslational protein targeting to membrane

Protein targeting to ER

SRP-dependent cotranslational protein targeting to membrane

Protein localization to endoplasmic reticulum

Establishment of protein localization to endoplasmic reticulum

Nuclear-transcribed mRNA catabolic process

mRNA catabolic process

Translational initiation
B.

$24 \mathrm{~h}$

Pathway

Regulation of cell division

Endothelial cell migration

Sprouting angiogenesis

Protein localization to organelle

Blood vessel endothelial cell migration

Chromosome segregation

Epithelial cell migration

Ameboidal-type cell migration

Viral life cycle

Tissue migration

$48 \mathrm{~h}$

$0.5 \quad 4.60 E-05$

$4.50 E-04$

Epithelial cell migration

Epithelium migration

Tissue migration

Cell junction assembly

Regulation of cell migration involved in sprouting angiogenesis

Regulation of sprouting angiogenesis

Regulation of blood vessel endothelial cell migration

Carbohydrate biosynthetic process

Blood vessel endothelial cell migration

Cell junction organization

$96 \mathrm{~h}$

8.03E-03

8.03E-03

$0.0 \quad 6.80 \mathrm{E}-24 \quad$ Notch signaling pathway

$0.1 \quad 1.70 \mathrm{E}-22$

Response to endoplasmic reticulum stress

Peptidyl-proline hydroxylation

Post-translational protein modification

$3.90 \mathrm{E}-21$

Positive regulation of gene expression (epigenetic)

4.70E-21

4.80E-21

Regulation of mRNA catabolic process

Maintenance of protein localization in organelle

2.10E-20

$0.1 \quad 4.10 E-20$

Maintenance of protein localization in endoplasmic reticulum

$0.12 .70 \mathrm{E}-19$

Notch signaling involved in heart development

Vesicle targeting to, from or within Golgi
Ratio p-value

$0.3 \quad 1.90 \mathrm{E}-05$

$0.3 \quad 2.20 \mathrm{E}-05$

$0.4 \quad 2.80 \mathrm{E}-05$

$0.4 \quad 3.00 \mathrm{E}-05$

$0.4 \quad 3.50 \mathrm{E}-05$

$0.2 \quad 4.90 \mathrm{E}-05$

$0.5 \quad 1.10 \mathrm{E}-04$

$0.5 \quad 1.10 E-04$

$0.4 \quad 1.30 \mathrm{E}-04$

$0.5 \quad 1.30 \mathrm{E}-04$

$0.4 \quad 3.00 E-04$

$0.4 \quad 3.70 E-04$

$0.43 .70 E-04$

$0.4 \quad 4.20 E-04$

$0.3 \quad 5.20 E-04$

$0.3 \quad 5.20 E-04$

$0.2 \quad 5.30 E-04$

$0.4 \quad 5.40 E-04$

$0.4 \quad 5.60 E-04$

$0.4 \quad 6.10 E-04$

$0.3 \quad 8.20 E-05$

$0.4 \quad 8.20 E-05$

$0.2 \quad 2.17 E-03$

$0.3 \quad 2.17 E-03$

$0.3 \quad 2.91 E-03$

$0.3 \quad 2.95 E-03$

$0.1 \quad 3.35 E-03$

$0.0 \quad 3.35 E-03$

$0.2 \quad 3.98 E-03$

$0.0 \quad 4.03 \mathrm{E}-03$

Pathways in italic are coculture enriched pathways identified in both comparisons for that specific time point. The 2 nd column represents the ratio of upregulated and downregulated genes in the pathway under study (ratio $\geq 0.5$ )

\section{Influence of pericytes on signaling pathways in brain-like endothelial cells}

Although, focusing on individual genes might be an easy way to discover novel genes related to BBB formation and maintenance, it is essential to identify how different genes interact with each other in order to fully understand the dynamic regulation of the BBB [5].

Therefore, pathway analysis is a valuable tool to find groups of functionally important genes [24]. Induction and formation occurs through a multiple-step process 
Table 8 Top differentially expressed pathways for the comparison of soloculture vs. coculture with bovine pericytes (CBP) at $24 \mathrm{~h}$

\begin{tabular}{|c|c|c|}
\hline Term & Database & Corrected p-value \\
\hline Osteoclast differentiation & KEGG & $8.46 \mathrm{E}-04$ \\
\hline $\begin{array}{l}\text { Regulation of insulin-like growth factor (IGF) transport and uptake by insulin-like growth } \\
\text { factor binding proteins (IGFBPs) }\end{array}$ & Reactome & 0.001 \\
\hline Cytokine Signaling In Immune System & Reactome & 0.002 \\
\hline Syndecan interactions & Reactome & 0.003 \\
\hline Extracellular matrix organization & Reactome & 0.004 \\
\hline TNF signaling pathway & KEGG & 0.004 \\
\hline Notch signaling pathway & PANTHER & 0.006 \\
\hline Immune system & Reactome & 0.006 \\
\hline Cell surface interactions at the vascular wall & Reactome & 0.012 \\
\hline Non-integrin membrane-ECM interactions & Reactome & 0.014 \\
\hline Interferon alpha/beta signaling & Reactome & 0.017 \\
\hline Interferon signaling & Reactome & 0.019 \\
\hline Hemostasis & Reactome & 0.020 \\
\hline ECM proteoglycans & Reactome & 0.022 \\
\hline Platelet degranulation & Reactome & 0.022 \\
\hline Response to elevated platelet cytosolic Ca2+ & Reactome & 0.024 \\
\hline Nicotine degradation & PANTHER & 0.028 \\
\hline Molecules associated with elastic fibers & Reactome & 0.029 \\
\hline Integrin cell surface interactions & Reactome & 0.030 \\
\hline Tryptophan metabolism & KEGG & 0.031 \\
\hline Hepatitis B & KEGG & 0.032 \\
\hline PECAM1 interactions & Reactome & 0.040 \\
\hline Elastic fiber formation & Reactome & 0.041 \\
\hline AGE-RAGE signaling pathway in diabetic complications & KEGG & 0.046 \\
\hline GRB2/SOS provides linkage to MAPK signaling for Integrins & Reactome & 0.047 \\
\hline
\end{tabular}

Pathway analysis was conducted using different databases i.e. KEGG pathway, Reactome and Panther [37]. Statistical analysis was performed using the Fisher's exact test and false discovery rate correction test was performed by the Benjamini and Hochberg method [3]

comprising a broad variety of signaling pathways, all directed by signals of different cell types. For example, vascular endothelial growth factor (VEGF)-related pathways such as the p38/MAPK pathway, play a key regulative role in proliferation, survival and migration of ECs [30]. Other signaling pathways like TGF-b, Angpt 1 and 2, notch and the phosphoinositide 3-kinase (PI3K) pathway are essential for BBB development and maintenance, by supporting a pericyte function. The latter is demonstrated by studies that show defective BBB formation upon pericyte absence [11, 22, 30].

Our results indicate significant association of multiple pathways expressed in ECs with the introduction of brain pericytes. However, the Wnt pathway, which is one of the most important pathways known to regulate $\mathrm{BBB}$ formation, does not show to be differentially expressed in ECs between solo- and cocultures. The Wnt pathway is known to induce BBB features such as the expression of tight junctions and expression of specific transporters (e.g. SLC2A1 or GLUT-1), and central nervous system-specific angiogenesis during embryogenesis $[24,30]$. Except for SLC2A1, other Wnt-related genes known to be regulated by b-catenin (e.g. LEF1, APCDD1, AXIN2, STRA6, SLC2A1) are, at the contrary, only poorly expressed in our study [30]. Nevertheless, these results might just indicate an earlier time point of activation of this pathway than the time points considered within this study. This would be in line with the fact that induction of BBB properties is initiated by Wnt activation by neural precursors [5]. Considering the previous, we should be aware of the presence of other important pathways and signaling cascades that take place at an earlier time point than the first analysed time point in this study (i.e. $24 \mathrm{~h}$ ).

Although, some important pathways were discovered over the years, many of the molecular mechanisms behind pericyte-endothelial interactions or behind BBB formation and maintenance are yet to be discovered. The results obtained in this study might be used in further analysis. 
Table 9 Top differentially expressed pathways for the comparison of soloculture vs. coculture with human pericytes (CHP) at $24 \mathrm{~h}$

\begin{tabular}{lll}
\hline Term & Database & $\begin{array}{c}\text { Corrected } \\
\text { p-value }\end{array}$ \\
\hline AGE-RAGE signaling pathway in diabetic complications & KEGG & 0.002 \\
Hemostasis & Reactome \\
Cell adhesion molecules (CAMs) & KEGG & 0.002 \\
Senescence-associated secretory phenotype (SASP) & Reactome & 0.006 \\
TNF signaling pathway & KEGG \\
CCKR signaling map & PANTHER & 0.007 \\
Cell surface interactions at the vascular wall & Reactome & 0.009 \\
Chemokine signaling pathway & KEGG & 0.009 \\
Osteoclast differentiation & KEGG & 0.014 \\
Signaling by cytosolic FGFR1 fusion mutants & Reactome & 0.016 \\
Syndecan interactions & Reactome & 0.022 \\
Estrogen signaling pathway & KEGG & 0.023 \\
Extracellular matrix organization & Reactome & 0.025 \\
Propanoate metabolism & KEGG \\
2-Oxobutanoate degradation & BioCyc & 0.032 \\
Valine, leucine and isoleucine degradation & KEGG \\
Integrin cell surface interactions & Reactome & 0.035 \\
Immune system & Reactome & 0.036 \\
\hline
\end{tabular}

Pathway analysis was conducted using different databases i.e. KEGG pathway, Reactome and Panther. Statistical analysis was performed using the Fisher's exact test and false discovery rate correction test was performed by the Benjamini and Hochberg method [3]

Table 10 Top differentially expressed pathways for the comparison of soloculture vs. coculture with bovine pericytes (CBP) at $96 \mathrm{~h}$

\begin{tabular}{|c|c|c|}
\hline Term & Database & Corrected p-value \\
\hline $\begin{array}{l}\text { Regulation of insulin-like growth factor (IGF) transport and uptake by insulin-like growth fac- } \\
\text { tor binding proteins (IGFBPs) }\end{array}$ & Reactome & $3.31 \mathrm{E}-04$ \\
\hline Gap junction assembly & Reactome & 0.003 \\
\hline Gap junction trafficking & Reactome & 0.008 \\
\hline Gap junction trafficking and regulation & Reactome & 0.008 \\
\hline Degradation of the extracellular matrix & Reactome & 0.012 \\
\hline Inhibition of voltage gated $\mathrm{Ca}^{2+}$ channels via beta/gamma subunits & Reactome & 0.015 \\
\hline Activation of $\mathrm{G}$ protein gated potassium channels & Reactome & 0.015 \\
\hline G protein gated potassium channels & Reactome & 0.015 \\
\hline Cell cycle, mitotic & Reactome & 0.018 \\
\hline Cell cycle & Reactome & 0.020 \\
\hline Extracellular matrix organization & Reactome & 0.021 \\
\hline Inwardly rectifying $\mathrm{K}^{+}$channels & Reactome & 0.027 \\
\hline Phenylalanine metabolism & KEGG & 0.027 \\
\hline Deposition of new CENPA-containing nucleosomes at the centromere & Reactome & 0.038 \\
\hline Nucleosome assembly & Reactome & 0.038 \\
\hline Intrinsic pathway of fibrin clot formation & Reactome & 0.047 \\
\hline GABA B receptor activation & Reactome & 0.048 \\
\hline Activation of GABAB receptors & Reactome & 0.048 \\
\hline
\end{tabular}

Pathway analysis was conducted using different databases i.e. KEGG pathway, Reactome and Panther. Statistical analysis was performed using the Fisher's exact test and false discovery rate correction test was performed by the Benjamini and Hochberg method [3] 
Table 11 Top differentially expressed pathways for the comparison of soloculture vs. coculture with human pericytes (CHP) at $96 \mathrm{~h}$

\begin{tabular}{llc}
\hline Term & Database & Corrected p-value \\
\hline RHO GTPase effectors & Reactome & $1.02 \mathrm{E}-04$ \\
DNA methylation & Reactome & 0.004 \\
SIRT1 negatively regulates rRNA expression & Reactome & 0.005 \\
Activated PKN1 stimulates transcription of AR (androgen receptor) regulated genes KLK2 and KLK3 & Reactome & 0.005 \\
RHO GTPases activate formins & Reactome & 0.008 \\
RNA polymerase I promoter opening & Reactome & 0.009 \\
B-WICH complex positively regulates rRNA expression & Reactome & 0.010 \\
RHO GTPases activate PKNs & Reactome & 0.0131 \\
Signal Transduction & Reactome & 0.022 \\
Formation of the beta-catenin/TCF transactivating complex & Reactome & 0.024 \\
G1/S-specific transcription & Reactome \\
Mineral absorption & KEGG & 0.026 \\
Epigenetic regulation of gene expression & Reactome & 0.032 \\
Extracellular matrix organization & Reactome & 0.038 \\
Regulation of insulin-like growth factor (IGF) transport and uptake by insulin-like growth factor binding & Reactome & 0.041 \\
$\quad$ proteins (IGFBPs) & & 0.046
\end{tabular}

Pathway analysis was conducted using different databases i.e. KEGG pathway, Reactome and Panther. Statistical analysis was performed using the Fisher's exact test and false discovery rate correction test was performed by the Benjamini and Hochberg method [3]

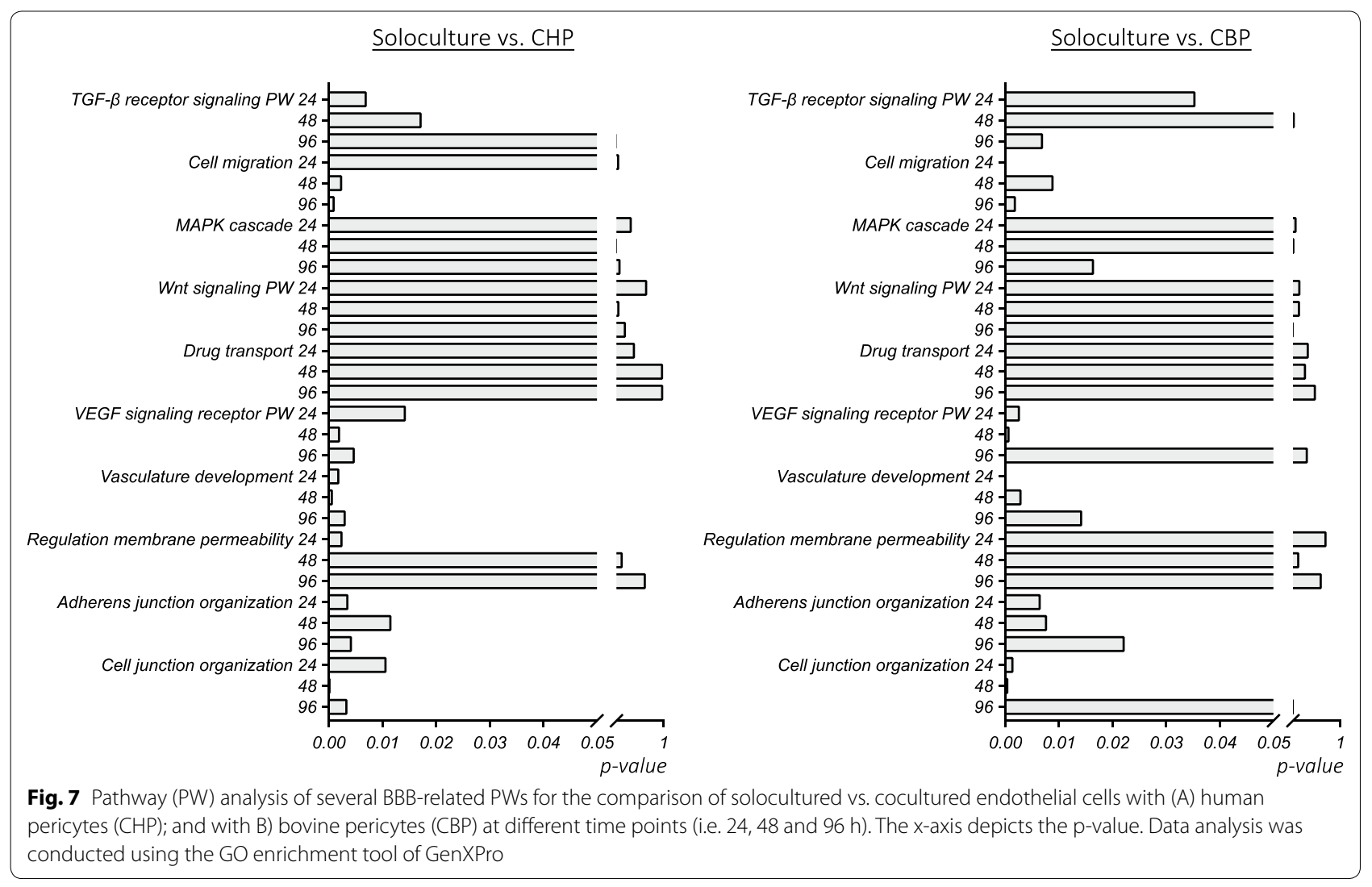




\section{Conclusion}

$\mathrm{BBB}$ formation and maintenance are complexly regulated by several pathways and signaling cascades, which are activated by different kind of signals. The processes are known to be regulated in a spatial-temporal manner and involve the interaction of different cell types of the NVU and brain ECs [5]. Human in vivo assessment of the molecular mechanisms behind BBB formation and maintenance is hampered by ethical and practical issues. However, well-designed in vitro models that use human cells from a different origin (e.g. stem cells) can greatly benefit this research because of their non-invasiveness and 'easy-to-handle'-characteristics. They also circumvent the many obstacles related to the use of primary human brain cells which is evidenced by the cumbersome extraction of pure brain capillary ECs out of human brain tissue [24]. Although, advancements over the last years in purification techniques (e.g. fluorescence-activated cell sorting and magnetic bead immunoprecipitation) do enhance research possibilities, and in vitro models using human stem cells are still beneficial as availability of healthy human brain tissue is scarce. In vitro models allow to focus on the interaction between ECs and other cell types of the NVU, thereby decomposing the contribution of different elements of the NVU. Of course, it should be emphasized that this type of studies does not represent the whole BBB physiology, as it lacks several components like the extracellular matrix or other cell types of the NVU, however, the use of these in vitro BBB models in RNA sequencing analysis can reveal enriched genes and pathways that are involved in the response of ECs to paracrine signals delivered by brain pericytes. Besides lacking physiological parameters, sequencing of additional samples would ameliorate the statistical power for identification of significantly differentially expressed genes. Unlike qRT-PCR, RNA sequencing allows the evaluation of all potential important genes as the method does not rely on the use of specific probes for detection of initially chosen genes [34].

This study therefore performed RNA sequencing (MACE) of ECs derived from cord-blood hematopoietic stem cells that were cultured in absence (i.e. soloculture) or presence (i.e. coculture) of brain pericytes. Comparison of both transcriptomes resulted in the identification of a set of upregulated genes in soloculture conditions (soloculture enriched genes) and a set of upregulated genes in coculture conditions (coculture enriched genes). Thereby, several typical BBB genes showed an upregulation, as well as several typical vascular genes showed a downregulation in coculture conditions.

Besides transcriptomics, all other types of 'omics' (e.g. proteomics, metabolomics and lipidomics) can be complementary used to provide crucial details on the actual output of these enriched genes as it is known that transcript abundance show low correspondence to protein level [24]. Integration of these different types of datasets can result in a more comprehensive image of the BBB vasculature [24, 38]. Therefore, the transcriptomic datasets that resulted from this study provide a starting point to discover the mechanisms behind BBB formation and maintenance for further validation of interesting soloculture and coculture enriched genes or for micro RNA (miRNA) analysis. miRNAs are known to be capable of individually regulating many mRNA transcripts by mRNA degradation or inhibition of protein translation [31]. Several studies thereby evidence an important role of endogenous miRNAs in the regulation of BBB function [26]. Preliminary evaluation of miRNA expression, for which data is not shown, resulted in the identification of some specific significantly altered miRNAs. Analysis of target genes regulated by these miRNAs subsequently identified a number solo- or coculture enriched transcripts, which suggests importance of miRNA in the regulation of enriched genes. Further analysis, that links dysregulated miRNA expression to differentially expressed genes that are likely related to BBB formation and maintenance, might therefore be essential to provide a complete understanding of the regulation of important BBB genes.

The number of transcriptomic profiling studies of the endothelial barriers, including the $\mathrm{BBB}$, and vasculature in general, did drastically increase over the last years. The latter resulted in the development of transcriptomic databases [38]. The power of these databases is underestimated as they bear a massive amount of valuable data. Although comparative studies of transcriptomic data can be trivial, it may further delineate the molecular mechanisms behind BBB formation and BBB maintenance.

Within the framework of the European Brain Barriers Training Network (H2020-MSCA-ITN-2015), called BtRAIN, a BBBHub (Interfaculty Bioinformatics Unit, UBern, Switzerland) is currently being developed in order to collect and disseminate transcriptomic (resulting from RNA sequencing) data from a variety of studies (in vitro and in vivo, across different species). The transcriptomic data generated in this study will be available in this BBBHub (http://bbbhub.unibe.ch/) upon launch which will allow further use of this data in comparative cross-species and cross-system analysis, due to homogeny of the data analysis process and the presence of substantial metadata. This will further validate the data obtained in this study. For example, a drawback of the present study is the sole analysis of the $\mathrm{BBB}$ in static conditions, as the experimental design is lacking physiological parameters such as mechanical 
forces (e.g. shear stress). The latter is demonstrated to increase the ECs expression of cytoskeletal genes [24]. It would therefore be valuable to compare genes that were found to be enriched in the present study to the transcriptomic profile of cocultured ECs in dynamic, flow conditions. However, caution should be made when comparing datasets from different studies as different experimental conditions with different variables pose a challenge for generating conclusive interpretations e.g. inter-individual and regional variability [4, 38].

\section{Supplementary information}

Supplementary information accompanies this paper at https://doi. org/10.1186/s12987-020-00208-1.

Additional file 1. Supplementary table depicting sequencing statistics. Number of raw reads sequenced and number of unique reads after removal of duplicates generated during polymerase chain reaction.

\section{Abbreviations}

ABC: ATP-binding cassette; BBB: Blood-brain barrier; BCRP: Breast cancer resistance protein; CHP: Coculture with human pericytes; CBP: Coculture with bovine pericytes; EC: Endtohelial cells; GF: Elacridar; GO: Gene ontology; LY: Lucifer yellow; MACE: Massive Analysis of cDNA Ends; miRNA: micro RNA; NVU: Neurovascular unit; Pe: Permeability coefficient; P-gp: P-Glycoprotein; R123: Rhodamine 123; RH: Krebs-Ringer HEPES buffer.

\section{Acknowledgements}

The authors thank the European Commission for funding this study within the framework of a Marie Sklodowska-Curie Innovative Training Network: BtRAIN (H2020-MSCA-ITN-2015, no 675619) and the coordinator of the BtRAIN project Pr. Britta Engelhardt.

\section{Authors' contributions}

$\mathrm{MH}$ and $\mathrm{MC}$ conceived and planned the experiments. RB, BE, PW and FG provided critical feedback on the experimental plan and the findings of the study. YS, FS and TK provided the human brain pericytes. MH and LD carried out the in vitro experiments. RF carried out the next-generation sequencing. DF assisted with the handling of the sequencing data and their integration in the BBB Hub. MH wrote the manuscript with support from MC. All authors read and approved the final manuscript.

\section{Funding}

This work was supported by funding from the European Commission within the framework of a Marie Sklodowska-Curie Innovative Training Network: BtRAIN_European Brain Barriers Training Network (H2020-MSCA-ITN-2015, no 675619).

\section{Competing interests}

The authors declare that the research was conducted in the absence of any commercial or financial relationships that could be construed as a potential conflict of interest.

\footnotetext{
Author details

${ }^{1}$ Laboratoire de la Barrière Hémato-Encéphalique (LBHE), Univ. Artois, UR 2465, 62300 Lens, France. ${ }^{2}$ GenXPro GmbH, Frankfurt, Germany. ${ }^{3}$ Johann Wolfgang Goethe University Frankfurt, Frankfurt, Germany. ${ }^{4}$ Interfaculty Bioinformatics Unit and Swiss, Institute of Bioinformatics, University of Bern, Bern, Switzerland. ${ }^{5}$ Department of Neurology and Clinical Neuroscience, Graduate School of Medicine, Yamaguchi University, Ube, Japan. ${ }^{6}$ Theodor Kocher Institute, University of Bern, Bern, Switzerland.
}

Received: 4 February 2020 Accepted: 13 July 2020

Published online: 28 July 2020

\section{References}

1. Abbott J, Patabendige AAK, Dolman DEM, Yusof SR, Begley DJ. Structure and function of the blood-brain barrier. Neurobiol Dis. 2010;37(1):13-25. https://doi.org/10.1016/j.nbd.2009.07.030.

2. Aday S, Cecchelli R, Hallier-Vanuxeem D, Dehouck MP, Ferreira L. Stem cell-based human blood-brain barrier models for drug discovery and delivery. Trends Biotechnol. 2016;34:5. https://doi.org/10.1016/j.tibte ch.2016.01.001.

3. Benjamini Y, Hochberg Y. Controlling the false discovery rate: a practical and powerful approach to multiple testing. J R Stat Soc. 1995;57(1):289-300.

4. Billington S, Salphati L, Hop CECA, Chu X, Evers R, Burdette D, et al. Interindividual and regional variability in drug transporter abundance at the human blood-brain barrier measured by quantitative targeted proteomics. Am Soc Clin Pharmacol Ther. 2019. https://doi.org/10.1002/cpt.1373.

5. Blanchette $M$, Daneman R. Formation and maintenance of the BBB. Mech Dev. 2015;138:8-16. https://doi.org/10.1016/j.mod.2015.07.007.

6. Butler LM, Hallström BM, Fagerberg L, Pontén F, Uhlén M, Renné T, et al. Analysis of body-wide unfractionated tissue data to identify a core human endothelial transcriptome. Cell Syst. 2016;3:287-301. https://doi. org/10.1016/j.cels.2016.08.001.

7. Cecchelli R, Aday S, Sevin E, Almeida C, Culot M, Dehouck L, et al. A stable and reproducible human blood-brain barrier model derived from hematopoietic stem cells. PLoS ONE. 2014;9(6):e99733. https://doi.org/10.1371/ journal.pone.0099733.

8. Chen Y, Liu L. Modern methods for delivery of drugs across the blood-brain barrier. Adv Drug Deliv Rev. 2012;64:640-65. https://doi. org/10.1016/j.addr.2011.11.010.

9. Cochrane A, Albers HJ, Passier R, Mummery Cl, van den Berg A, Orlova W, et al. Advanced in vitro models of vascular biology: human induced pluripotent stem cells and organ-on-chip technology. Adv Drug Deliv Rev. 2018. https://doi.org/10.1016/j.addr.2018.06.007.

10. Daneman R, Zhou L, Agalliu D, Cahoy JD, Kaushal A, Barres BA. The mouse blood-brain barrier transcriptome: a new resource for understanding the development and function of brain endothelial cells. PLOS ONE. 2010;5:e13741. https://doi.org/10.1371/journal.pone.0013741.

11. Daneman R, Zhou L, Kebede AA, Barres BA. Pericytes are required for blood-brain barrier integrity during embryogenesis. Nature. 2010;468:562-6. https://doi.org/10.1038/nature09513.

12. Dehouck MP, Méresse S, Delorme P, Fruchart JC, Cecchelli R. An easier, reproducible, and mass-production method to study the bloodbrain barrier in vitro. J Neurochem. 1990;54(5):1798-801. https://doi. org/10.1111/j.1471-4159.1990.tb01236.x.

13. Deli MA, Csongor SA, Katoaka Y, Niwa M. Permeability studies on in vitro blood-brain barrier models: physiology, pathology and pharmacology. Cell Mol Neurobiol. 2005;25(1):59-127. https://doi.org/10.1007/s1057 1-004-1377-8.

14. Delsing L, Dönnes P, Sanchez J, Clausen M, Voulgaris D, Falk A, et al. Barrier properties and transcriptome expression in human iPSC-derived models of the blood-brain barrier. Stem cells. 2018. https://doi.org/10.1002/ stem.2908.

15. Dohgu S, Takata F, Yamauchi A, Nakagawa S, Egawa T, Naito M, et al. Brain pericytes contribute to the induction and up-regulation of blood-brain barrier functions through transforming growth factor-h production. Brain Res. 2005;1038:208-15. https://doi.org/10.1016/j.brainres.2005.01.027.

16. Garberg P, Ball M, Borg N, Cecchelli R, Fenart L, Hurst RD, et al. In vitro models for the blood-brain barrier. Toxicol In Vitro. 2004;19:299-334. https://doi.org/10.1016/j.tiv.2004.06.011.

17. Girbl T, Lenn T, Perez L, Rolas L, Barkaway A, Thiriot A, et al. Distinct compartmentalization of the chemokines CXCL1 and CXCL2 and the atypical receptor ACKR1 determine discrete stages of neutrophil diapedesis. Immunity. 2018;49(6):1062-76. https://doi.org/10.1016/j.immun i.2018.09.018.

18. Glass K, Girvan M. Annotation enrichment analysis: an alternative method for evaluating the functional properties of gene sets. Sci Rep. 2014;4:4191. https://doi.org/10.1038/srep04191. 
19. Goddard LM, Iruela-Arispe ML. Cellular and molecular regulation of vascular permeability. Thrombosis Haemostasis. 2013;109(3):407-15. https:// doi.org/10.1160/TH12-09-0678.

20. Günzel D, Yu ASL. Claudins and the modulation of tight junction permeability. Physiol Rev. 2013;93:525-69. https://doi.org/10.1152/physr ev.00019.2012.

21. Hayashi K, Saitou M. Perspectives of germ cell development in vitro in mammals. Anim Sci J. 2004;85:617-26. https://doi.org/10.1111/asj.12199.

22. Hill J, Rom S, Ramirez SH, Persidsky Y. Emerging roles of pericytes in the regulation of the neurovascular unit in health and disease. J Neuroimmune Pharmacol. 2015;9(5):591-605. https://doi.org/10.1007/s1148 1-014-9557-x

23. Hori S, Ohtsuki S, Hosoya KI, Nakashima E, Terasaki T. A pericyte-derived angiopoietin-1 multimeric complex induces occluding gene expression in brain capillary endothelial cells through Tie-2 activation in vitro. J Neurochem. 2004;89:503-13. https://doi.org/10.1111/j.1471-4159.2004.02343 x.

24. Huntley MA, Bien-Ly N, Daneman R, Watts RJ. Dissecting gene expression at the blood-brain barrier. Front Neurosci. 2014;8:355. https://doi. org/10.3389/fnins.2014.00355.

25. Hyung SW, Jung YS. Hypoxia induces FoxO3a-mediated dysfunction of blood-brain barrier. Biochem Biophys Res Commun. 2014;450(4):163842. https://doi.org/10.1016/j.bbrc.2014.07.055.

26. Lopez-Ramirez MA, Wu D, Pryce G, Simpson JE, Reijerkerk A, King-Robson $J$, et al. MicroRNA-155 negatively affects blood-brain barrier function during neuroinflammation. Feder Am Soc Exp Biol J. 2014;28(6):2551-65. https://doi.org/10.1096/f.13-248880.

27. Love IM, Huber W, Anders S. Moderated estimation of fold change and dispersion for RNA-seq data with DESeq2. Genome Biol. 2014;15(550):121. https://doi.org/10.1186/s13059-014-0550-8.

28. Munji RN, Soung AL, Weiner GA, Sohet F, Semple BD, Trivedi A, et al. Profiling the mouse brain endothelial transcriptome in health and disease models reveals a core blood-brain barrier dysfunction module. Nat Neurosci. 2019;22:1892-902. https://doi.org/10.1038/s41593-019-0497-X.

29. Nold-Petry CA, Lo CY, Rudloff I, Li S, Gantier MP, Lotz-Havla AS, et al. IL-37 requires the receptors IL-18Ra and IL-1R8 (SIGIRR) to carry out its multifaceted anti-inflammatory program upon innate signal transduction. Nat Immunol. 2015;16(4):354-65. https://doi.org/10.1038/ni.3103.

30. Obermeier B, Daneman R, Ransohoff RM. Development, maintenance and disruption of the blood-brain barrier. Nat Med. 2013;19(12):1584-96. https://doi.org/10.1038/nm.3407.
31. Shah PP, Hutchinson LE, Kakar SS. Emerging role of microRNAs in diagnosis and treatment of various diseases including ovarian cancer. J Ovarian Res. 2009;2:11. https://doi.org/10.1186/1757-2215-2-11.

32. Shimizu F, Sano Y, Abe MA, Maeda T, Ohtsuki S, Terasaki T, et al. Peripheral nerve pericytes modify the blood-brain barrier function and tight junctional molecules through the secretion of various soluble factors. J Cell Physiol. 2011;226(1):255-66. https://doi.org/10.1002/jcp.22337.

33. Siflinger-Birnboim A, Del Vecchio P, Cooper JA, Blumenstock FA, Shepard JM, Malik AR. Molecular sieving characteristics of the cultured endothelial monolayer. J Cell Physiol. 1987;132:111-7. https://doi.org/10.1002/ jcp.1041320115.

34. Suhy AM, Webb A, Papp AC, Geier EG, Sadee W. Expression and splicing of $A B C$ and SLC transporters in the blood-brain barrier measured with RNASeq. Eur J Pharm Sci. 2017;103:47-51. https://doi.org/10.1016/j. ejps.2017.02.010.

35. Thiriot A, Perdomo C, Cheng G, Novitzky-Basso I, McArdle S, Kishimoto JK, et al. Differential DARC/ACRK1 expression distinguishes venular from non-venular endothelial cells in murine tissues. BMC Biol. 2017;15:45. https://doi.org/10.1186/s12915-017-0381-7.

36. Vandenhaute E, Dehouck L, Boucau MC, Sevin E, Uzbekov R, Tardivel M, et al. Modelling the neurovascular unit and the blood-brain barrier with the unique function of pericytes. Curr Neurovasc Res. 2011;8(4):258-69. https://doi.org/10.2174/156720211798121016.

37. Xie C, Mao X, Huang J, Ding Y, Wu J, Dong S, et al. KOBAS 2.0: a web server for annotation and identification of enriched pathways and diseases. Nucleic Acids Res. 2011;39:316-22. https://doi.org/10.1093/nar/gkr483.

38. Xu S. Transcriptome profiling systems vascular medicine. Front Pharmacol. 2017;8:1-9. https://doi.org/10.3389/fphar.2017.00563.

\section{Publisher's Note}

Springer Nature remains neutral with regard to jurisdictional claims in published maps and institutional affiliations.
Ready to submit your research? Choose BMC and benefit from:

- fast, convenient online submission

- thorough peer review by experienced researchers in your field

- rapid publication on acceptance

- support for research data, including large and complex data types

- gold Open Access which fosters wider collaboration and increased citations

- maximum visibility for your research: over $100 \mathrm{M}$ website views per year

At BMC, research is always in progress.

Learn more biomedcentral.com/submissions 